\begin{tabular}{|l|l|}
\hline $\begin{array}{l}\text { Postprint } \\
\text { Version }\end{array}$ & 1.0 \\
\hline Journal website & http://www.pec-iournal.com/article/S0738-3991(16)30079-9/fulltext \\
\hline Pubmed link & https://www.ncbi.nlm.nih.gov/pubmed/26954345 \\
\hline DOI & $10.1016 /$ j.pec.2016.02.012
\end{tabular}

This is a NIVEL certified Post Print, more info at http://www.nivel.eu

\title{
Exploring effectiveness and effective components of self- management interventions for young people with chronic physical conditions: A systematic review
}

\section{HighLights}

- We explored the effectiveness and effective elements of self-management programs.

- The quality of evidence varies on outcomes from very low to moderate.

- Programs may positively affect knowledge, adherence, and dealing with the condition.

- Online peer-support might improve dealing with the condition.

- Programs with individual sessions or in a clinical setting might improve adherence

\begin{abstract}
Objective: To systematically explore the effectiveness and effective components of self-management interventions.

Methods: Study selection criteria were: Original articles in English published between 2003 and 2015; focusing on youth with chronic conditions; describing self-management interventions; with clear outcome measures; using RCT design. The random effects analysis was applied in which standardized mean differences per study were calculated.

Results: 42 RCTs were included. Interventions focused on medical management, provided individually in clinical settings or at home by monodisciplinary teams showed a trend in improving adherence. Interventions delivered individually at home by mono-disciplinary teams showed a trend in improving dealing with a chronic condition.

Conclusions and practical implications: Adherence could be improved through interventions focused on medical management, provided individually in a clinical or home setting by a mono-disciplinary team. Interventions focused on dealing with a chronic condition might be provided individually, through telemedicine programs facilitating peer-support. These intervention elements seemed effective irrespective of diagnosis, and may therefore act as good starting points for further research into and for improvement of self-
\end{abstract}


Bal, M.I., Sattoe, J.N.T., Roelofs, P.D.D.M., Bal, R., Staa, A. van, Miedema, H.S. Exploring effectiveness and effective components of self-management interventions for young people with chronic physical conditions: a systematic review. Patient Education and Counseling 2016,7 99(8), 1293-1309

management support for youth with chronic conditions in pediatric care. Results underlined the need to systematically develop and evaluate self-management interventions, since this may provide more evidence for effectiveness and effective intervention components.

\section{INTRODUCTION}

Advancements in medical care result in increasing numbers of young people with chronic conditions making the transition into adulthood $[1,2]$. This transition, which implies becoming an independent adult fulfilling different roles in society, requires complicated life changes [3,4]. For these young people the transition may be more complicated, however, as they often lag behind in social and emotional development compared to healthy peers $[5,6]$. Furthermore, they are expected to take over the task of medical management from their parents, but this does not always come with ease $[7,8]$. It seems crucial, therefore, to help them develop self-management skills in all life areas [9-11]. Barlow et al. define self-management as "the individual's ability to manage the symptoms and the consequences of living with a chronic condition, including treatment, physical, social, and lifestyle changes [12]". As such, selfmanagement and self-management support encompass three elements: medical management (considering the treatment), role management (considering participation in society), and emotion management (considering emotional consequences of being ill) [13]. This broad definition of self-management is widely used, as it fits with the World Health Organization's definition of health in terms of physical, mental and social well-being [14].

A range of interventions is available for healthcare providers to support young people's self-management in chronic disease $[9-11,15,16]$. These interventions are developed for young people aged between 7 and 25 years. The age of seven years is considered as a developmentally appropriate age to start the development of independence and young adults are still developing their full potential $[17,18,19]$. Self-management interventions have been reviewed in some studies [20,21], but solid evidence on effectiveness of self-management interventions (SMI) for young people with chronic conditions in general, i.e. irrespective of diagnosis, is still lacking [20-26]. Specifically, Kirk et al. [21] restricted themselves to asthma, cystic fibrosis and diabetes, while Lindsay et al. [20] restricted themselves to physical disabilities, excluding people with somatic chronic conditions. Moreover, although Kirk et al. [21] reviewed effective components of SMI for young people with asthma, cystic fibrosis and diabetes, insights into effective intervention components of selfmanagement support for young people with a variety of chronic conditions are still lacking [20].

Still, looking at self-management support through a non-categorical approach is important [27]. Despite disease-specific differences, there are many commonalities between young people with chronic conditions, as they face comparable challenges and similar adaptive tasks while growing up [22]. A non-categorical approach to selfmanagement support may benefit both health service delivery and research [28]. First, because it could allow pediatric teams to learn from other specialist teams, for instance by using (partly) the same SMI. Second, it could stimulate the use of same outcomes measures, which could enhanced the evaluation of effectiveness of these programs [28]. 
Bal, M.I., Sattoe, J.N.T., Roelofs, P.D.D.M., Bal, R., Staa, A. van, Miedema, H.S. Exploring effectiveness and effective components of self-management interventions for young people with chronic physical conditions: a systematic review. Patient Education and Counseling:2016,7 99(8), 1293-1309

In a parallel paper including SMI evaluation studies using all kinds of study designs, a systematic overview of self-management support for youth with chronic conditions in general with respect to content, formats, theories, and evaluated outcomes is provided [29]. This systematic overview showed that most interventions were aimed at medical management, and that no theoretical base was provided for most of the included interventions. Although a variety of outcomes was evaluated, outcomes were conceptually related to specific content [29]. No results about effectiveness of SMI were included in this overview. Therefore, in the current paper, we reviewed published randomized controlled trials (RCT) of these SMI elaborating on (a) evidence regarding effectiveness of SMI focused on youth with chronic conditions; and (b) effective intervention components of these SMI, by employing a noncategorical approach to chronic conditions. Such insights may provide understanding of what elements of self-management support might be effective across a variety of chronic physical conditions, and hence may be valuable to further improve selfmanagement support in health care.

\section{METHODS}

\subsection{Study design}

We applied a systematic review methodology which Grant and Booth defined as "systematically searching for, appraising and synthesizing research evidence, often adhering to guidelines for conducting a review" [30]. Methodological characteristics according to the 'Search, Appraisal, Synthesis and Analysis' (SALSA) framework are: exhaustive and comprehensive searching, quality assessment, narrative synthesis with tabular accompaniment, results of uncertainty around findings, recommendations for practice and future research [30]. This type of review allows for exploration of effects and effective intervention components of self-management support. The PRISMA statement guided the review process [31].

\subsection{Search strategy}

The search strategy employed variations and Boolean connections (AND, OR) of subject headings and keywords relating to self-management, children and adolescents, chronic illness, and intervention. For example, MESH terms (Medical Subject Headings) included: "Self care", "Self medication", "Intervention studies", Program evaluation", "Chronic disease", "Disabled person", "Adolescence", "Child". Key words included: "self help" "clinical effectiveness"; "evaluation"; "congenital disorder"; "handicapped child"; "youth"; "teenage". Relevant variations of search terms were derived from database thesauruses and relevant review articles. An information specialist helped define the final search strategy. Six databases were searched: Embase; Medline; PsycINFO; Web-of-Science; CINAHL; and Cochrane. Two researchers (MB; JS) completed the database searches by scrutinizing relevant reviews' references for additional relevant publications.

\subsection{Inclusion criteria}

- Study design: studies using a randomized controlled study design.

- Study types: original research articles in English language published from 2003 to April 2015, because the focus in literature on self-management rapidly increased since 2003 [32].

- Interventions: studies focusing on the evaluation of SMI and describing the SMI or referring to previous description(s) of the intervention. 
Bal, M.I., Sattoe, J.N.T., Roelofs, P.D.D.M., Bal, R., Staa, A. van, Miedema, H.S. Exploring effectiveness and effective components of self-management interventions for young people with chronic physical conditions: a systematic review. Patient Education and Counseling:2016,7 99(8), 1293-1309

- Outcome measures: studies considering clearly defined outcome measures.

- Participants: studies focusing on young people aged 7-25 years with somatic chronic conditions or physical disability. The age of seven years is considered a developmentally appropriate age to start the development of independence [17]. As young adults are still developing their full potential, the age range was extended from 18 to 25 years $[18,19]$.

Studies had to meet all inclusion criteria to be included for further analysis.

\subsection{Selection, quality assessment, and data extraction}

Retrieved records $(n=7505)$ identified in databases and relevant reviews' reference lists were imported into Endnote X7.2 ${ }^{\circledR}$. Two reviewers (MB, JS) independently categorized studies into: 'include', 'exclude' or 'not clear' based on title and abstract. Thereafter, the reviewers discussed the studies for which inclusion/exclusion was unclear and aimed to reach consensus on the decision. If doubt remained, a third reviewer was consulted (PR). Full texts of all agreed-upon articles $(n=562)$ were retrieved. Then, the two reviewers independently decided on the inclusion of articles based on the full text, resulting in 85 publications. For this paper we were interested in effects and effective intervention components, in contrast to the parallel paper [29], and therefore selected studies with RCT design $(n=42)$ from the included publications. The selection process and reasons for exclusion are presented in Fig. 1. Three reviewers (MB, JS, PR) independently assessed methodological quality of all included studies using the methodology checklists of the Scottish Intercollegiate Guidelines Network (SIGN) for randomized controlled trials [33]. Methodological quality was defined as high when at least eight out of ten criteria were met; as moderate when from five till eight were met; and as low when fewer than five criteria were met [33]. Any discrepancies in assessment of methodological quality were resolved by discussion. Two reviewers (MB, JS) extracted data on study design; study sample; self-management domain considered during the intervention; interventions' theoretical base, format, discipline, interventionist, element, setting, outcome measures and study results [34]. Data was recorded on an electronic extraction form.

\section{[FIGURE 1]}

\subsection{Analysis}

The following seven categories of outcome measures were inductively derived from the data: (1) symptoms; (2) disease knowledge; (3) adherence; (4) dealing with the chronic condition (including self-efficacy, coping and problem-solving); (5) psychological outcomes (including depression, stress, anxiety); (6) school attendance; and (7) quality of life. The reviewers (MB, JS) independently clustered the specific study outcome measures into these categories.

The overall quality of evidence for each outcome measure was independently rated by two researchers (MB\&JS) using the GRADE approach, a method for rating the quality of evidence and grading the strength of recommendations per particular outcome [35]. Basically, evidence of randomized controlled trials (RCT's) is rated as high but may be modified downwards on the basis of five different criteria: (1) risk of bias: assessment of methodological quality; (2) inconsistency: heterogeneity or 
Bal, M.I., Sattoe, J.N.T., Roelofs, P.D.D.M., Bal, R., Staa, A. van, Miedema, H.S. Exploring effectiveness and effective components of self-management interventions for young people with chronic physical conditions: a systematic review. Patient Education and Counseling 2016,7 99(8), 1293-1309

variability in results across studies; (3) indirectness of evidence: indirect comparison of interventions within the studies; (4) imprecision of results: wide confidence intervals around the estimate of the effect; and (5) likeliness of publication bias: underestimating or overestimating of the effect due to the selective publication of studies [36-40]. Problems on a criterion was defined as serious when $60-80 \%$ of the studies showed limitations, and very serious when $>80 \%$ of the studies showed limitations on the criterion. The quality of evidence per outcome measure (high) was single downgraded for serious study limitations to moderate quality of evidence, and double downgraded for very serious study limitations to low quality of evidence. Analyses to explore the effectiveness and the effective intervention components of self-management support were performed for each outcome measure separately. The random effects analysis was applied in which standardized mean differences per study were calculated [41]. In this way, we could compare effect sizes of statistically heterogeneous studies and provide an overview of effects on an outcome measure measured with different measurement instruments. Pooled estimates were not calculated, because interventions were clinically diverse, i.e. consisted of different intervention elements, and studies were statistically diverse, i.e. different instruments were used to evaluate the interventions. In addition, to evaluate the effective intervention components, we compared the effect sizes of included studies that differed on particular intervention components. For instance, effect sizes of individual intervention programs were compared with effect sizes of group intervention programs. Likewise, effect sizes of interventions focusing on different self-management domains, or provided by different disciplines, interventionists, and in various settings were compared. We speak of 'a trend in favor of', because we could not perform a meta-analysis (due to the heterogeneity in measurement instruments) and thus cannot state whether an intervention or its components are indeed effective or not. We only described a pattern of effects when at least three studies were included, and used the cut-off point of two out of three studies (67\%) as a minimum number of studies indicating effects in the same direction. Otherwise, the pattern was described as showing no clear effects. When drawing conclusions, we downgraded the level of evidence for those issues where the number of available studies was low [38]. Individual studies that showed a significant effect were weighted twice and individual studies that showed a trend (but not a significant effect) were weighted once. Review Manager version 5.1 software was used for the analyses.

\section{RESULTS}

\subsection{Paralell paper}

A detailed overview of the focus and content of the interventions presented in the parallel paper, showed a variety in the operationalization of self-management support [29]. Most SMI were aimed at medical management, neglecting psychosocial challenges. Although a variety of outcomes was evaluated, outcomes were conceptually related to specific content [29]. In order to explore the effectiveness and effective components of SMI, we selected the studies with RCT-design from the included studies $(n=42)$. In the current paper results on effectiveness and effective components of SMI are described. 
Bal, M.I., Sattoe, J.N.T., Roelofs, P.D.D.M., Bal, R., Staa, A. van, Miedema, H.S. Exploring effectiveness and effective components of self-management interventions for young people with chronic physical conditions: a systematic review. Patient Education and Counseling 2016,7 99(8), 1293-1309

\subsection{General study characteristics $(n=42)$}

- Countries: Most, studies were performed in the USA $(n=27)$, followed by Australia $(n=3)$, Canada $(n=2)$, Taiwan $(n=2)$, the Netherlands $(n=2)$, the United Kingdom $(n=2)$, China $(n=1)$, Germany $(n=1)$, and Jordan and Australia $(n=1)$. - Chronic conditions: Study participants were patients with asthma $(n=16)$, diabetes $(n=6)$, cystic fibroses $(n=3)$, cancer $(n=2)$, human immunodeficiency virus infection $(n=2)$, sickle cell disease $(n=2)$, or other diseases (e.g. spina bifida, haemophilia and juvenile fibromyalgia) $(n=9)$.

- Methodologicalquality: The methodological quality of 25 studies was rated as moderate, of 11 studies as high and of 6 studies as low.

\subsection{Intervention components $(n=42)$}

Many interventions were solely aimed at medical management (61.9\%). Medical management was either disease-specific or more general. Disease-specific medical management refers to tasks or topics associated with or related to a specific diagnosis, e.g. self-monitoring of blood glucose values in diabetes. General medical management refers to health and healthcare related tasks irrespective of diagnosis. For instance, accessing healthcare, but also child-parent sharing or teamwork related to medical management tasks. One intervention considered only role management (2.4\%), referring to topics related to social participation, such as communicating, assertiveness and keeping up with peers. None of the interventions considered emotion management separately. Interventions considering emotion management could refer to young person's feelings and intrinsic characteristics. Topics covered are stress-management and relaxation techniques. The other interventions addressed multiple domains, for example both on medical and role management (35.7\%). Studies did not mention a theoretical base for the intervention (64.3\%), referred to learning theories like Bandura's (cognitive) social learning theory $(11,9 \%)$, cognitive behavioral theory $(4,4 \%)$ or a combination of these $(2,4 \%)$. Interventions were either applied at individual level (69.0\%), at group level (23.8\%) or both (7.1\%). Most interventions were provided by a mono-disciplinary team (70\%). Interventions included education $(88.1 \%)$, peer-support $(23.8 \%)$, problem solving $(23.8 \%)$, relaxation training $(21.4 \%)$, cognitive restructuring (e.g. cognitive behavioral therapy) (19.0\%), or self-monitoring, (e.g. keeping a diary with blood glucose values) $(19.0 \%)$. In general, neither the domain of self-management considered during interventions nor the other intervention elements were specifically linked to certain theoretical frameworks. Intervention settings were inpatient or outpatient clinics $(31.0 \%)$, home $(23.8 \%)$, online (14.3\%), school (14.3\%), home and clinic (7.1\%), camping sites $(4.8 \%)$, or home and school (2.3\%). Settings were not exclusive for formats and elements of interventions.

A detailed description of study characteristics and intervention components per study is presented in Appendix A.

\subsection{Exploration of effectiveness and effective components of self-management interventions}

\subsubsection{Outcome measure symptoms}

Twenty-four studies focused on the severity of symptoms as an outcome measure [43,49-51,54,56,58-60,63-67,70,72,74,76-83]. In general, SMI showed a trend in favor of the control condition. Specifically, nine studies showed a trend in favor of 
Bal, M.I., Sattoe, J.N.T., Roelofs, P.D.D.M., Bal, R., Staa, A. van, Miedema, H.S. Exploring effectiveness and effective components of self-management interventions for young people with chronic physical conditions: a systematic review. Patient Education and Counseling 2016,7 99(8), 1293-1309

intervention; twelve studies reported a trend in favor of the control condition; and three studies showed a significant effect in favor of the control condition. The quality of evidence was very low (Table 1).

\section{[TABLE 1]}

Of all interventions that aims to reduce the severity of symptoms, the interventions focused on medical management, medical and role management, or medical management, emotion management and role management showed a trend in favor of the control condition. The same pattern held for interventions delivered by a psychologist. Also, interventions provided in a clinic, online, or at home and in a clinic showed a trend in favor of the control condition. In contrast, interventions provided at home showed a trend in favor of intervention (Fig. 2a-c).

\section{[FIGURE 2]}

\subsubsection{Outcome measure disease knowledge}

Nineteen studies focused on disease knowledge as an outcome measure $[42,43,45,47,48,52-55,57,61-63,66,71,73,76,78,82]$. In general, SMI showed a trend in favor of intervention. Specifically, nine studies revealed a significant effect in favor of intervention; five studies showed a trend in favor of intervention and five studies showed a trend in favor of the control condition. The quality of evidence was moderate (Table 1).

Of all interventions that aims to improve disease knowledge, interventions focused on medical management, or medical management, emotional management and role management, showed a trend in favor of intervention. The same pattern revealed for interventions provided individually and interventions provided in a clinic or at home. Mono-disciplinary interventions showed a trend in favor of the control condition, but this was also the case for multi-disciplinary interventions (Fig. 3a and b).

\section{[FIGURE 3].}

3.4.3. Outcome measure adherence

Nine studies focused on adherence as an outcome measure

$[45,53,54,61,67,68,78,82,83]$. Overall, SMI showed a positive trend on adherence. Specifically, four studies showed a significant effect in favor of intervention, five other studies showed a positive tendency. The quality of evidence was very low (Table 1).

Of all interventions that aims to improve adherence, interventions focused on medical management showed a trend in favor of intervention. The same pattern held for interventions provided individually and in a clinic or at home and interventions delivered mono-disciplinary (Fig. 4a and b).

\section{[FIGURE 4]}

\subsubsection{Outcome measure dealing with the chronic condition in daily life}

Eleven studies focused on dealing with the chronic condition in daily life as an outcome measure $[42,43,47,48,52,54,57,61,69,73,78]$. Overall, no clear effects of 
Bal, M.I., Sattoe, J.N.T., Roelofs, P.D.D.M., Bal, R., Staa, A. van, Miedema, H.S. Exploring effectiveness and effective components of self-management interventions for young people with chronic physical conditions: a systematic review. Patient Education and Counseling 2016,7 99(8), 1293-1309

SMI were found on dealing with the chronic condition in daily life. Specifically, two studies had a significant effect in favor of intervention; five studies had a trend in favor of intervention. In contrast, three studies revealed a trend in favor of the control condition and one study showed a significant effect in favor of the control condition. The quality of evidence was very low (Table 1).

Of all interventions that aims to improve dealing with chronic condition in daily life, interventions focused on medical management, showed a trend in favor of intervention. The same pattern held for mono-disciplinary interventions provided individually and at home. In contrast, interventions provided online showed a trend in favor of the control condition (Fig. 5a and b).

\section{[FIGURE 5]}

3.4.5. Outcome measure psychological outcomes

Nine studies focused on psychological outcomes [44,46,49,59-61,69,72,75,78]. In general, no clear effects of SMI were found on this outcome measure. Specifically, one study had a significant effect in favor of intervention; two studies showed a positive tendency; and six others showed a trend in favor of the control condition. The quality of evidence was very low (Table 1).

Of all interventions that aims to improve psychological outcomes, interventions focused on medical management, showed a trend in favor of the control condition. The same pattern was revealed for mono-disciplinary interventions and interventions provided individually by a psychologist and online. In contrast, interventions provided in groups showed a trend in favor of intervention (Fig. 6a-c).

\subsubsection{Outcome measure school attendance}

Five studies focused on school attendance as an outcome measure [43,58,62,63,79]. SMI showed a trend in favor of the control condition: two studies showed a significant effect in favor of the control condition one study showed a negative tendency, while two studies showed a trend in favor of intervention. The quality of evidence was very low (Table 1).

No clear pattern was revealed for intervention components.

\subsubsection{Outcome measure quality of life}

Thirteen studies focused on quality of life as an outcome measure [42,44,47$50,57,58,61,65,70,74,78]$. Overall, no clear effects of SMI were found on quality of life. Four studies had a significant effect in favor of intervention; three studies showed a trend in favor of intervention; one study showed a significant effect in favor of the control condition; four studies showed a trend in favor of the control condition. The quality of evidence was high (Table 1).

Of all interventions that aims to improve quality of life, interventions focused on medical management showed a trend in favor of intervention (Fig. 7). 
Bal, M.I., Sattoe, J.N.T., Roelofs, P.D.D.M., Bal, R., Staa, A. van, Miedema, H.S. Exploring effectiveness and effective components of self-management interventions for young people with chronic physical conditions: a systematic review. Patient Education and Counseling 2016,7 99(8), 1293-1309

\section{[FIGURE 7]}

\section{DISCUSSION AND CONCLUSION}

\subsection{Discussion}

We reviewed randomized controlled trials to explore the effectiveness and effective intervention components of SMI. In contrast to existing literature, we looked at pediatric SMI in general, i.e. irrespective of type of condition. Our findings suggests that pediatric SMI might be effective at influencing disease knowledge, adherence, but not at symptom severity and school attendance. Conflicting evidence was found for effectiveness of SMI on dealing with the chronic condition, psychological outcomes and quality of life. However, results about effectiveness should be interpreted with some caution, because the quality of evidence for most outcome measures was rated as low. In addition, some evidence was found for effective intervention components, but this differs per outcome measure.

\subsubsection{Effectiveness of SMI}

Possible evidence for effectiveness of SMI on disease knowledge was also reported in previous reviews on SMI for adult patients $[12,84]$. Others showed possible evidence for effectiveness of SMI on disease knowledge of youth with spina bifida, arthritis, asthma, or diabetes [17,18,85-87] and for effectiveness of pediatric SMI on adherence [88-90]. Moreover, earlier studies on youth showed that both knowledge about the condition and medication adherence are important to maintain health [91]. Although Kirk et al. [21] underlined the need to incorporate patient-centered outcomes such as quality of life and psychosocial well-being into SMI evaluation studies, conflicting evidence for effectiveness of SMI on these outcome measures was found and inconsistent results have been reported by others [12,84]. Nolte et al. [92] pointed out that patient reported outcomes measures (e.g. quality of life and psychosocial well-being) are highly variable, since these require the highest degree of personal appraisal. Specifically, people may define depression or quality of life very differently before SMI compared to after intervention, influencing the reliability of measurements. These biases could have influenced the results of included studies and, thus, our results. However, patient reported outcomes do provide insights into patients' lived experiences and are therefore highly relevant for studying selfmanagement. Therefore, future studies designed to explore response shifts are recommended. For instance, qualitative methods may shed light on how a patient's context interacts with their lived experiences. This is in line with the recently posed notion that patient's context is important to consider when researching selfmanagement [93].

\subsubsection{Effective components of SMI}

In addition to previous research on effectiveness of SMI [17,18,21], this review revealed some suggestions about components of SMI to be effective. Specifically, SMI aimed to improve adherence might be effective when focused on medical management and provided individually in a clinic or at home by a mono-disciplinary team. This is not surprising, since adherence is part of medical management and individual attention of one professional may enhance insights into personal barriers to adherence. 
Bal, M.I., Sattoe, J.N.T., Roelofs, P.D.D.M., Bal, R., Staa, A. van, Miedema, H.S. Exploring effectiveness and effective components of self-management interventions for young people with chronic physical conditions: a systematic review. Patient Education and Counseling 2016,7 99(8), 1293-1309

We found some evidence that SMI aiming to support young people to deal with the chronic condition in daily life should focus on medical management, emotion management and role management, i.e. should consider a holistic view on selfmanagement $[13,22]$. This conclusion is in line with earlier findings showing that one's illness behavior depends on one's perception of symptoms and on the extent to which symptoms interfere with daily life [94], i.e. one's lived experiences [95,96]. In this light, the support need on dealing with chronic conditions in daily life is influenced by lived experiences, and SMI on this outcome measure should therefore include role management and emotion management, besides medical management [13]. In addition, our review suggests that these SMI might be mono-disciplinary programs, provided individually and at home. These findings are somewhat unexpected since peer-support was found to be an appropriate element to stimulate dealing with the chronic condition in daily life, i.e. enhance self-efficacy, and therefore we expected group sessions and a clinical setting to be effective intervention elements [97,98]. However, taking a closer look at elements used in these SMI, we conclude that these individually provided programs facilitate peersupport using telemedicine element. This indicates that online peer-support could also be an appropriate element to improve self-efficacy, problem solving skills and pro-active coping behavior, as was earlier mentioned in literature [18]. However, more research is needed to further validate this hypothesis, since we found some evidence that interventions provided online without a peer-support element might not be effective.

Our review suggests, too, that a mono-disciplinary team, an online setting and an individual format might not be effective intervention components of selfmanagement support focused on psychological outcomes, i.e. stress, anxiety and depression. In contrast, we found some evidence for group sessions to be an effective intervention component. Earlier research showed the perceived distress of people with chronic conditions and their need for social support [99]. It might be necessary, therefore, to incorporate elements that promote people's sense of empowerment into SMI, if aiming to improve psychological outcomes [100,101]. In addition cognitive behavioral therapy is commonly used in the treatment of depression. According to the rationale behind the therapy, cognitive social learning theory, people should adapt their maladaptive cognitions and modify their behavior to reduce the depressive symptoms [102]. Group meetings may help to discuss maladaptive cognitions and behaviors, and may help to change these into more adaptive ones. Also, our review suggests that SMI aimed to target psychological outcomes might not be focused on medical management. This is not unexpected, because emotion management or a combination of emotion management with role and/or medical management might be a more appropriate content for SMI aiming to reduce stress, anxiety and depression.

Furthermore, we found that programs on symptom reduction should be provided at home instead of in a clinic, home and clinic or online. An explanation for this finding could be that symptoms arise in interacting with the social context. In line with this reasoning, SMI could be more effective when provided in people's daily life. For example, Reeves et al. [103] indicated the importance of social community to fulfill self-management tasks. However, Krieger et al. [104] reviewed pediatric asthma interventions and found both home and clinical settings to be effective for symptom reduction. Also, no clear effects were found for any other intervention components. 
Bal, M.I., Sattoe, J.N.T., Roelofs, P.D.D.M., Bal, R., Staa, A. van, Miedema, H.S. Exploring effectiveness and effective components of self-management interventions for young people with chronic physical conditions: a systematic review. Patient Education and Counseling:2016,7 99(8), 1293-1309

Elements of SMI on symptom reduction seem to be too diverse and sample sizes are too small, which hampers the evaluation of working elements of these interventions. It seems that the development of SMI is often not based on theories [21,24,25,29]. Therefore, it is recommended to further standardize the development of SMI, and thus to explicitly use theoretical frameworks when designing interventions. Also, it could be that symptoms are too disease-specific and therefore effects on symptom reduction could not be appropriately analyzed in a review of SMI focusing on a variety of chronic conditions. Therefore it would be favorable to employ a disease specific approach, when exploring effects of SMI on symptom reduction.

\subsubsection{Strengths limitations and other considerations}

SMI for young people across the wide age range of 7-25 years were included, while content or themes obviously are not applicable to the whole age range, e.g. vocational participation pertains to older adolescents only. It would be advisable, therefore, to distinguish between age groups. However, a systematic overview of the content of SMI for young people aged between 7 and 25 years showed that interventions' theoretical base, formats and elements did not differ for different age groups [29].

This study looked at many types of SMI across a wide range of chronic conditions. The breadth of this study is a potential strength. The findings enable researchers and healthcare professionals to look at general self-management support, which goes beyond particular chronic conditions. In addition, subgroup analyses - not presented in this paper - showed no differences in effects between interventions focused on a distinctive diagnosis.

Last, the, in general, low quality of evidence for most outcome measures as rated using the GRADE methodology [35], downgrades the strength of recommendations per outcome measure. The low quality of evidence was mainly caused by the variability and heterogeneity of study results. Also it was not possible to perform a meta-analysis on the effects of SMI, since the outcome measures and intervention programs were very heterogeneous. Therefore, results about effectiveness should be interpreted with some caution. Different conceptualizations of self-management might be one explanation for the diversity of elements and content of SMI and the variety of outcome measures used in SMI evaluation studies, which points at a more fundamental challenge to provide precise definitions [105]. Others, too, recommended to further standardize the development and evaluation of selfmanagement interventions [16,17,84]. Intervention mapping methodology [98] is a recommended stepwise approach for theory and evidence-based development and implementation of interventions that helps to fit intervention goals with program development and program evaluation. In addition, a theoretically derived intervention would make for a more effective SMI, using components that have been found to be effective in changing that specific outcome [106].

\subsection{Conclusions}

Our review suggests that pediatric SMI might be effective at influencing disease knowledge and adherence across a wide range of conditions. There are indications that SMI aimed to improve adherence should be focused on medical management, and should be provided individually in a clinical setting or at home by a monodisciplinary team. Furthermore, a holistic view on self-management, individual format and home setting combined with online peer-support might be effective 
Bal, M.I., Sattoe, J.N.T., Roelofs, P.D.D.M., Bal, R., Staa, A. van, Miedema, H.S. Exploring effectiveness and effective components of self-management interventions for young people with chronic physical conditions: a systematic review. Patient Education and Counseling 2016,7 99(8), 1293-1309

intervention components for SMI focused on dealing with the chronic condition in daily life. These combinations of expected outcomes, focus and intervention elements seemed effective irrespective of diagnosis, and may therefore act as good starting points for further improvement of and research into self-management support of young people with chronic conditions in health care. Results underlined the need to systematically develop and evaluate self-management interventions, since this may provide more evidence for effectiveness and effective intervention components.

\subsection{Practical implications}

Self-management support is important for people with chronic conditions to help them deal with their condition in daily life. This is even more pertinent to young people growing up with chronic conditions, who have to face the normal tasks of development (e.g. acquiring autonomy) and have to engage in lifelong medical management of their condition. Our systematic overview of effectiveness and effective intervention components may assist clinicians and other healthcare professionals in determining the focus, content and components of self-management support they provide. More specifically, to improve patient's adherence, healthcare professionals should focus their SMI on medical management, and they should provide the intervention individually in a clinical setting or at home by a monodisciplinary team. Furthermore, a holistic view on self-management, individual format and home setting combined with online peer-support might be appropriate intervention components to select for SMI focused on dealing with the chronic condition in daily life.

\section{Conflict of interest}

The authors have no potential conflicts of interests to declare, including relevant financial interests, activities, relationships, and affiliations.

\section{Funding}

The study was part of the Self-management and Participation Innovation Lab, supported by SIA-RAAK, the Foundation Innovation Alliance with funding from the Dutch ministry of Education, Culture and Science (PRO-02-025).

\section{Acknowledgements}

The authors thank the information specialist of the Erasmus MC-medical library, W. Bramer MCs, for his assistance in defining the search strategy. Ko Hagoort is thanked for his editorial assistance.

\section{[APPENDIX A. SUPPLEMENTARY DATA]}

\section{REFERENCES}

[1] P.H. White. Access to health care: health insurance considerations for young adults with special health care needs/disabilities. Pediatrics, 110 (2002), pp. 1328-1335

[2]World Health Organization, World report on disability. 2010-cited 2014 September 16. Available from: http://whqlibdoc. who.int/publications/2011/9789240685215 eng.pdf?ua=1.

[3] E. Verhoof, H. Maurice-Stam, H. Heymans, M. Grootenhuis. Growing into disability benefits: psychosocial course of life of young adults with a chronic somatic disease or disability. Acta Paediatr., 101 (2012), pp. 19-26

[4] Y. Ratanachadawan. A response to Koch T, Jenkin P, Kralik D. (2004). Chronic illness self-management: locating the 'self'. J. Adv. Nurs., 52 (2005), pp. 571-572 
Bal, M.I., Sattoe, J.N.T., Roelofs, P.D.D.M., Bal, R., Staa, A. van, Miedema, H.S. Exploring effectiveness and effective components of self-management interventions for young people with chronic physical conditions: a systematic review. Patient Education and Counseling 2016,7 99(8), 1293-1309

[5] M. Donkervoort, M. Roebroeck, D. Wiegerink, H. van der Heijden-Maessen, H. Stam. Transition research group South West N. Determinants of functioning of adolescents and young adults with cerebral palsy. Disabil. Rehabil., 29 (2007), pp. 453-463

[6] M.A. Chamberlain, R.M. Kent. The needs of young people with disabilities in transition from paediatric to adult services. Eura. Medicophys., 41 (2005), pp. 111-123

[7] B.H. Fiese, R.S. Everhart. Medical adherence and childhood chronic illness: family daily management skills and emotional climate as emerging contributors. Curr. Opin. Pediatr., 18 (5) (2006), pp. 551-557

[8] A.C. Modi, A.L. Pai, K.A. Hommel, K.K. Hood, S. Cortina, M.E. Hilliard, et al. Pediatric self-management: a framework for research, practice, and policy. Pediatric, 129 (2012), pp. 473-485

[9] P.W. Harvey, J.N. Petkov, G. Misan, J. Fuller, M.W. Battersby, T.N. Cayetano, K. Warren, $P$. Holmes. Self-management support and training for patients with chronic and complex conditions improves health-related behaviour and health outcomes. Aust. Health Rev., 32 (2008), pp. 330-338

[10] E.H. Wagner. Chronic disease management: what will it take to improve care for chronic illness Eff. Clin. Pract., 1 (1998), pp. 2-4

[11] J. Trappenburg, N. Jonkman, T. Jaarsma, H. van Os-Medendorp, H. Kort, N. de Wit, A. Hoes, M. Schuurmans Self-management: one size does not fit all. Patient Educ. Couns., 92 (2013), pp. 134-137

[12] J. Barlow, C. Wright, J. Sheasby, A. Turner, J. Hainsworth. Self-management approaches for people with chronic conditions: a review. Patient Educ. Couns., 48 (2002), pp. 177-187

[13] K.R. Lorig, H. Holman. Self-management education: history, definition, outcomes, and mechanisms. Ann. Behav. Med., 26 (2003), pp. 1-7

[14]World Health Organization, Constitution of the World Health Organization. 2006-cited 2014 September 16. Available from:http://www.who.int.proxy.library.uu.nl/governance/eb/who constitution en.pdf.

[15] E.H. Wagner, B.T. Austin, C. Davis, M. Hindmarsh, J. Schaefer, A. Bonomi. Improving chronic illness care: translating evidence into action Health Aff., 20 (2001), pp. 64-78

[16] E. Nolte, M. McKee Caring for people with chronic conditions: an introduction.

E. Nolte, M. McKee (Eds.), Caring for People with Chronic Conditions. A Health System Perspective, Open University Press, Berkshire (2008)

[17] C. Gall, S. Kingsnorth, H. Healy Growing up ready: a shared management approach Phys. Occup. Ther. Pediatr., 26 (2006), pp. 47-62

[18] C.W. Irwin Young adults are worse off than adolescents J. Adolesc. Health, 46 (2010), pp. 405-406

[19] B. Beresford, L. Stuttard. Young adults as users of adult healthcare: experiences of young adults with complex or life-limiting conditions. Clin. Med., 14 (2010), pp. 404-408

[20] S. Lindsay, S. Kingsnorth, C. McDougall, H. Keating. A systematic review of selfmanagement interventions for children and youth with physical disabilities Disabil. Rehabil., 36 (2014), pp. 276-288

[21] S. Kirk, S. Beatty, P. Callery, J. Gellatly, L. Milnes, S. Pryjmachuk. The effectiveness of self-care support interventions for children and young people with long-term conditions: a systematic review. Child Care Health Dev., 39 (2012), pp. 305-324

[22] S.M. Sawyer, S. Drew, M.S. Yeo, M.T. Britto. Adolescents with a chronic condition: challenges living, challenges treating. Lancet, 369 (2007), pp. 1481-1489

[23] L. Wittgenstein. Philosophical Investigations. Blackwell, Oxford (1958)

[24] S. Newman, L. Steed, K. Mulligan. Chronic Physical Illness: Self-management and Behavioural Interventions. Open University Press, New York (2009)

[25] H. Jonsdottir. Self-management programmes for people living with chronic obstructive pulmonary disease: a call for a reconceptualization. J. Clin. Nurs., 22 (2013), pp. 621-637

[26] D. Schulman-Green, S. Jaser, F. Martin, A. Alonzo, M. Grey, R. McCorkle, N.S.

Redeker, N. Reynolds, R. Whittemore. Processes of self-management in chronic illness. J. Nurs. Scholarsh., 44 (2012), pp. 136-144

[27] J.M. Perrin, W.E. MacLean, S.L. Gortmaker, K.N. Asher. Improving the psychological status of children with asthma: a randomized controlled trial. J. Dev. Behav. Pediatr., 13 (1992), pp. 241-247 
Bal, M.I., Sattoe, J.N.T., Roelofs, P.D.D.M., Bal, R., Staa, A. van, Miedema, H.S. Exploring effectiveness and effective components of self-management interventions for young people with chronic physical conditions: a systematic review. Patient Education and Counseling 2016,7 99(8), 1293-1309

[28] R.E. Stein, D.J. Jessop. What diagnosis does not tell: the case for a noncategorical approach to chronic illness in childhood. Soc. Sci. Med., 29 (1989), pp. 769-778

[29] J.N.T. Sattoe, M.I. Bal, P.D.D.M. Roelofs, R. Bal, H.S. Miedema, A.L. van Staa. Selfmanagement interventions for young people with chronic conditions: a systematic review.

Patient Educ. Couns., 98 (6) (2015), pp. 704-715

[30] M.J. Grant, A. Booth. A typology of reviews: an analysis of 14 review types and associated methodologies. Health Info. Libr. J., 26 (2009), pp. 91-108

[31] D. Moher, A. Liberati, J. Tetzlaff, D.G. Altman, The PRISMA Group. Preferred reporting items for systematic reviews and meta-analyses: the PRISMA statement. PLoS Med., 6 (7) (2009), p. e1000097

[32] Y. Lu, Z. Li, D. Arthur. Mapping publication status and exploring hotspots in a research field: chronic disease self-management. J. Adv. Nurs., 70 (2014), pp. 1837-1844

[33]Scottish Intercollegiate Guidelines Network, Critical appraisal: notes and checklists. 2012-cited 2013 June 17. Available from: http://www.sign.ac.uk/methodology/checklists.html\#.

[34] K.W. Davidson, M. Goldstein, R.M. Kaplan, P.G. Kaufmann, G.L. Knatterud, C.T. Orleans, B. Spring, K.J. Trudeau, E.P. Whitlock. Evidence-based behavioral medicine: what is it and how do we achieve it. Ann. Behav. Med., 26 (2003), pp. 161-171

[35] J.P.T. Higgins, S.E. Green. Cochrane Handbook for Systematic Reviews of Interventions version 5.1.0. The Cochrane Collaboration (2011)

[36] G. Guyatt, A.D. Oxman, E.A. Akl, R. Kunz, G. Vist, J. Brozek, S. Norris, Y. Falck-Ytter, P. Glasziou, H. DeBeer. GRADE guidelines: 1. Introduction-GRADE evidence profiles and summary of findings tables and others. J. Clin. Epidemiol., 64 (2011), pp. 383-394

[37] G.H. Guyatt, A.D. Oxman, R. Kunz, J. Woodcock, J. Brozek, M. Helfand, et al. GRADE guidelines: 8: rating the quality of evidence-indirectness. J. Clin. Epidemiol., 64 (2011), pp. 1303-1310

[38] G.H. Guyatt, A.D. Oxman, R. Kunz, J. Woodcock, J. Brozek, M. Helfand, et al.GRADE guidelines: 7: rating the quality of evidence-inconsistency. J. Clin. Epidemiol., 64 (2011), pp. 1294-1302

[39] G.H. Guyatt, A.D. Oxman, R. Kunz, J. Brozek, P. Alonso-Coello, D. Rind, et al. GRADE guidelines 6: rating the quality of evidence-imprecision. J. Clin. Epidemiol., 64 (2011), pp. 1283-1293

[40] J.L. Brozek, E.A. Akl, P. Alonso-Coello, D. Lang, R. Jaeschke, J.W. Williams, et al.Grading quality of evidence and strength of recommendations in clinical practice guidelines: part 1 of 3 . An overview of the GRADE approach and grading quality of evidence about interventions. Allergy, 64 (2009), pp. 669-677

[41] R. DerSimonian, N. Laird. Meta-analysis in clinical trials. Control. Clin. Trials, 7 (1986), pp. 177-188

[42] N. Al-sheyab, R. Gallagher, J. Crisp, S. Shah. Peer-led education for adolescents with asthma in Jordan: a cluster-randomized controlled trial. Pediatrics, 129 (2012), pp. 106-112

[43] L.P. Barakat, L.A. Schwartz, K.S. Salamon, J. Radcliffe. A family-based randomized controlled trial of pain intervention for adolescents with sickle cell disease. J. Pediatr. Hematol. Oncol., 32 (2010), pp. 540-547

[44] A. Beebe, E.W. Gelfand, B. Bender.A randomized trial to test the effectiveness of art therapy for children with asthma. J. Allergy Clin. Immunol., 126 (2010), pp. 263-266

[45] V.M. Berrien, J.C. Salazar, E. Reynolds, K. McKay. Group HIVMAI. Adherence to antiretroviral therapy in HIV-infected pediatric patients improves with home-based intensive nursing intervention. AIDS Patient Care STDS, 18 (2004), pp. 355-363

[46] C.L. Betz, K. Smith, K. Macias. Testing the transition preparation training program: a randomized controlled trial. Int. J. Child Adolesc. Health, 3 (2011), pp. 595-607

[47] V.R. Breakey, D.M. Ignas, A.V. Warias, M. White, V.S. Blanchette, J.N. Stinson. A pilot randomized control trial to evaluate the feasibility of an Internet-based self-management and transitional care program for youth with haemophilia. Haemophilia, 20 (2014), pp. 784793

[48] A. Butz, L. Pham, L. Lewis, C. Lewis, K. Hill, J. Walker, M. Winkelstein. Rural children with asthma: Impact of a parent and child asthma education program. J. Asthma, 42 (2005), pp. 813-821 
Bal, M.I., Sattoe, J.N.T., Roelofs, P.D.D.M., Bal, R., Staa, A. van, Miedema, H.S. Exploring effectiveness and effective components of self-management interventions for young people with chronic physical conditions: a systematic review. Patient Education and Counseling:2016, 99(8), 1293-1309

[49] L.C. Chiang, W.F. Ma, J.L. Huang, L.F. Tseng, K.C. Hsueh. Effect of relaxationbreathing training on anxiety and asthma signs/symptoms of children with moderate-tosevere asthma: a randomized controlled trial. Int. J. Nurs. Stud., 46 (2009), pp. 1061-1070

[50] .B.J. Christian, J.P. D'Auria. Building life skills for children with cystic fibrosis: effectiveness of an intervention. Nurs. Res., 55 (2006), pp. 300-307

[51] M. Connelly, M.A. Rapoff, N. Thompson, Connelly W. Headstrong. A pilot study of a CDROM intervention for recurrent pediatric headache. J. Pediatr. Psychol., 31 (2006), pp. 737-747

[52] M.A. Davis, A.L. Quittner, C.M. Stack, M.C.K. Yang. Controlled evaluation of the STARBRIGHT CD-ROM program for children and adolescents with cystic fibrosis. J. Pediatr. Psychol., 29 (2004), pp. 259-267

[53] J.A. Downs, C.M. Roberts, A.M. Blackmore, P.N. Le Souef, S.C. Jenkins. Benefits of an education programme on the self-management of aerosol and airway clearance treatments for children with cystic fibrosis. Chronic. Respir. Dis., 3 (2006), pp. 19-27

[54] V.L. Franklin, A. Waller, C. Pagliari, S.A. Greene. A randomized controlled trial of Sweet Talk, a text-messaging system to support young people with diabetes. Diabetes Med, 23 (2006), pp. 1332-1338

[55] K. Huss, M. Winkelstein, J. Nanda, P.L. Naumann, E.D. Sloand, R.W. Huss. Computer game for inner-city children does not improve asthma outcomes. J. Pediatr. Health Care, 17 (2003), pp. 72-78

[56] R.L. Jan, J.Y. Wang, M.C. Huang, S.M. Tseng, H.J. Su, L.F. Liu. An internet-based interactive telemonitoring system for improving childhood asthma outcomes in Taiwan. Telemed. J. E-Health, 13 (2007), pp. 257-268

[57] J.K. Jones, S.A. Kamani, P.J. Bush, K.A. Hennessy, A. Marfatia, A.T. Shad.

Development and evaluation of an educational interactive CD-ROM for teens with cancer. Pediatr. Blood Cancer, 55 (2010), pp. 512-519

[58] C.L. Joseph, E. Peterson, S. Havstad, C.C. Johnson, S. Hoerauf, S. Stringer, W. Gibson-Scipio, D.R. Ownby, J. Elston-Lafata, U. Pallonen. A web-based, tailored asthma management program for urban African-American high school students. Am. J. Respir. Crit. Care Med., 175 (2007), pp. 888-895

[59] S. Kashikar-Zuck, N.F. Swain, B.A. Jones. Efficacy of cognitive-behavioral intervention for juvenile primary fibromyalgia syndrome. J. Rheumatol., 32 (2005), pp. 1594-1602

[60] S. Kashikar-Zuck, T.V. Ting, L.M. Arnold, J. Bean, S.W. Powers, T.B. Graham, M.H. Passo, K.N. Schikler, P.J. Hashkes, S. Spalding, et al.Cognitive behavioral therapy for the treatment of juvenile fibromyalgia: a multisite, single-blind, randomized, controlled clinical trial. Arthritis Rheum., 64 (2012), pp. 297-305

[61] P.M. Kato, S.W. Cole, A.S. Bradlyn, B.H. Pollock. A video game improves behavioral outcomes in adolescents and young adults with cancer: a randomized trial. Pediatrics, 122 (2008), pp. 305-317

[62] K. Koontz, A.D. Short, K. Kalinyak, R.B. Noll. A randomized controlled pilot trial of a school intervention for children with sickle cell anemia. J. Pediatr. Psychol., 29 (2004), pp. 7-17

[63]. S. Krishna, B.D. Francisco, E.A. Balas, P. Konig, G.R. Graff, R.W. Madsen. Randomized trial. Internet-enabled interactive multimedia asthma education program: a randomized trial. Pediatrics, 111 (2003), pp. 503-510

[64] V.S. Kumar, K.J. Wentzell, T. Mikkelsen, A. Pentland, L.M. Laffel. The DAILY (daily automated intensive log for youth) trial: a wireless, portable system to improve adherence and glycemic control in youth with diabetes. Diabetes Technol. Ther., 6 (2004), pp. 445 453

[65]. L.M. Laffel, L. Vangsness, A. Connell, A. Goebel-Fabbri, D. Butler, B.J. Anderson. Impact of ambulatory, family-focused teamwork intervention on glycemic control in youth with type 1 diabetes. J. Pediatr., 142 (2003), pp. 409-416

[66] A.C. McPherson, C. Glazebrook, D. Forster, C. James, A. Smyth. A randomized controlled trial of an interactive educational computer package for children with asthma. Pediatrics, 117 (2006), pp. 1046-1054

[67] S.A. Mulvaney, R.L. Rothman, K.A. Wallston, C. Lybarger, M.S. Dietrich An internetbased program to improve self-management in adolescents with type 1 diabetes. Pediatr Diabetes Care, 33 (2010), pp. 602-604 
Bal, M.I., Sattoe, J.N.T., Roelofs, P.D.D.M., Bal, R., Staa, A. van, Miedema, H.S. Exploring effectiveness and effective components of self-management interventions for young people with chronic physical conditions: a systematic review. Patient Education and Counseling 2016,7 99(8), 1293-1309

[68] S. Naar-King, A.Y. Outlaw, M. Sarr, J.T. Parsons, M. Belzer, K. Macdonell, M. Tanney, S.J. Ondersma. Adolescent medicine network for HIVAI. Motivational enhancement system for adherence (MESA): pilot randomized trial of a brief computer-delivered prevention intervention for youth initiating antiretroviral treatment. J. Pediatr. Psychol., 38 (2013), pp. 638-648

[69] P.A. Newcombe, T.L. Dunn, L.M. Casey, J.K. Sheffield, H. Petsky, S. Anderson-James, A.B. Chang. Breathe easier online: evaluation of a randomized controlled pilot trial of an Internet-based intervention to improve well-being in children and adolescents with a chronic respiratory condition. J. Med. Internet Res., 14 (2012), pp. 115-126

[70] S.M. Ng, A.M. Li, V.W. Lou, I.F. Tso, P.Y. Wan, D.F. Chan. Incorporating family therapy into asthma group intervention: a randomized waitlist-controlled trial. Fam. Process, 47 (2008), pp. 115-130

[71] E. Nunn, B. King, C. Smart, D. Anderson. A randomized controlled trial of telephone calls to young patients with poorly controlled type 1 diabetes. Pediatr. Diabetes, 7 (2006), pp. 254-259

[72] T.M. Palermo, A.C. Wilson, M. Peters, A. Lewandowski, H. Somhegyi. Randomized controlled trial of an Internet-delivered family cognitive-behavioral therapy intervention for children and adolescents with chronic pain. Pain, 146 (2009), pp. 205-213

[73] E.R. Pulgaron, K.S. Salamon, C.A. Patterson, L.P. Barakat. A problem-solving intervention for children with persistent asthma: a pilot of a randomized trial at a pediatric summer camp. J. Asthma, 47 (2010), pp. 1031-1039

[74] H. Rhee, M.J. Belyea, J.F. Hunt, J. Brasch. Effects of a peer-led asthma selfmanagement program for adolescents. Arch. Pediatr. Adolesc. Med., 165 (2011), pp. 513519

[75]. L. Scholten, A.M. Willemen, B.F. Last, H. Maurice- Stam, E.M. Van Dijk, E. Ensink, M.A. Grootenhuis. Efficacy of psychosocial group intervention for children with chronic illness and their parents.Pediatrics, 131 (2013), pp. 1196-1203

[76] R.S. Shames, P. Sharek, M. Mayer, T.N. Robinson, E.G. Hoyte, F. Gonzalez-Hensley, D.A. Bergman, D.T. Umetsu. Effectiveness of a multicomponent self-management program in at-risk, school-aged children with asthma. Ann. Allergy Asthma Immunol., 92 (2004), pp. 611-618

[77] D. Staab, T.L. Diepgen, M. Fartasch, J. Kupfer, T. Lob-Corzilius, J. Ring, S. Scheewe, R. Scheidt, G. Schmid-Ott, C. Schnopp. Age related, structured educational programmes for the management of atopic dermatitis in children and adolescents: multicentre, randomised controlled trial. and others. BMJ, 332 (2006), pp. 933-938

[78] J.N. Stinson, P.J. McGrath, E.D. Hodnett, B.M. Feldman, C.M. Duffy, A.M. Huber, L.B. Tucker, C.R. Hetherington, S.M. Tse, L.R. Spiegel.An internet-based self-management program with telephone support for adolescents with arthritis: a pilot randomized controlled trial and others. J. Rheumatol., 37 (2010), pp. 1944-1952

[79] M. Stulemeijer, L.W.A.M. De Jong, T.J.W. Fiselier, S.W.B. Hoogveld, G. Bleijenberg. Cognitive behaviour therapy for adolescents with chronic fatigue syndrome: randomised controlled trial. Br. Med. J., 330 (2005), pp. 14-17

[80] B. Velsor-Friedrich, T. Pigott, B. Srof.A practitioner-based asthma intervention program with African American inner-city school children. J. Pediatr. Health Care, 19 (2005), pp. 163-171

[81] N. Walders, C. Kercsmar, M. Schluchter, S. Redline, H.L. Kirchner, D. Drotar. An interdisciplinary intervention for undertreated pediatric asthma. Chest, 129 (2006), pp. 292299

[82] J.M. Wiecha, W.G. Adams, D. Rybin, M. Rizzodepaoli, J. Keller, J.M. Clay Evaluation of a web-based asthma self-management system: a randomised controlled pilot trial. BMC Polm. Med., 15 (2015), p. 7

[83] T. Wysocki, M.A. Harris, L.M. Buckloh, D. Mertlich, A.S. Lochrie, N. Mauras, N.H. White. Randomized trial of behavioral family systems therapy for diabetes: maintenance of effects on diabetes outcomes in adolescents. Diabetes Care, 30 (2007), pp. 555-560

[84] S. Nolte, R.H. Osborne. A systematic review of outcomes of chronic disease selfmanagement interventions. Qual. Life Res., 22 (2013), pp. 1805-1816 
Bal, M.I., Sattoe, J.N.T., Roelofs, P.D.D.M., Bal, R., Staa, A. van, Miedema, H.S. Exploring effectiveness and effective components of self-management interventions for young people with chronic physical conditions: a systematic review. Patient Education and Counseling:2016,7 99(8), 1293-1309

[85] J. DeShazo, L. Harris, W. Pratt. Effective intervention or child's play: a review of video games for diabetes education. Diab. Technol. Ther., 12 (2010), pp. 815-822

[86] . Russell-Minda, J. Jutai, M. Speechley, K. Bradley, A. Chudyk, R. Petrella. Health technologies for monitoring and managing diabetes: a systematic review. J. Diab. Sci. Technol., 3 (2009), pp. 1460-1471

[87] D.M. Bravata, A.L. Gienger, J.E. Holty, V. Sundaram, N. Khazeni, P.H. Wise, K.M. McDonald, D.K. Owens. Quality improvement strategies for children with asthma: a systematic review. Arch. Pediatr. Adolesc. Med., 163 (2009), pp. 572-581

[88] A.J. Dean, J. Walters, A. Hall. A systematic review of interventions to enhance medication adherence in children and adolescents with chronic illness. Arch. Dis. Child, 95 (2010), pp. 717-723.

[89]. M.M. Graves, M.C. Roberts, M. Rapoff, A. Boyer. The efficacy of adherence interventions for chronically ill children: a meta-analytic review. J. Pediatr. Psychol., 35 (2010), pp. 368-382

[90] S. Kahana, D. Drotar, T. Frazier. Meta-analysis of psychological interventions to promote adherence to treatment in pediatric chronic health conditions. J. Pediatr. Psychol., 33 (2008), pp. 590-611

[91] S. Kingsnorth, H. Healy, C. Macarthur. Preparing for adulthood: a systematic review of life skill programs for youth with physical disabilities. J. Adolesc. Health, 41 (2007), pp. 323-332

[92] S. Nolte, G.R. Elsworth, S. Newman, R.H. Osborne. Measurement issues in the evaluation of chronic disease self-management programs. Qual. Life Res., 22 (2013), pp. 1655-1664

[93] M.L. Thirsk, A.M. Clark. What is the 'self' in chronic disease self-management? Int. J. Nurs. Stud., 51 (2014), pp. 691-693

[94] D. Mechanic, E.H. Volkart. Illness behaviour and medical diagnosis . J. Health Hum. Behav., 1 (1960), pp. 86-94

[95] K. Atkin, S. Stapley, A. Easton. No one listens to me, nobody believes me: self management and the experience of living with encephalitis. Soc. Sci. Med., 71 (2010), pp. 386-393

[96] C. Gately, A. Rogers, C. Sanders. Re-thinking the relationship between long-term condition self-management education and the utilisation of health services. Soc. Sci. Med., 65 (2007), pp. 934-945

[97] A. Bandura. Social Learning Theory General. Learning Press, New York (1977)

[98] L.K. Bartholomew, G.S. Parcel, G. Kok, N.H. Gottlieb, M.E. Fernandez. Planning Health Promotion Programs: An Intervention Mapping Approach. (3rd edition), Jossey-Bass, SanFrancisco (2011)

[99] C. Li, E. Ford, G. Zhao, T.W. Strine, S. Dhingra, L. Barker, J.T. Berry, A.H. Mokdad. Association between diagnosed diabetes and serious psychological distress among $\mathrm{U} S$. adults: the behavioral risk factor surveillance system, 2007.Int. J. Public Health, 54 (2009), pp. $43-51$

[100] R.K. Dishman, D.P. Hales, K.A. Pfeiffer, G.A. Felton, R. Saunders, D.S. Ward, M. Dowda, R.R. Pate. Physical self-concept and self-esteem mediate cross-sectional relations of physical activity and sport participation with depression symptoms among adolescent girls. Health Psychol., 25 (2006), pp. 396-407

[101] E.S. Rogers, J. Chamberlin, M.L. Ellison, T. Crean. A consumer-constructed scale to measure empowerment among users of mental health services. Psychiatric Serv., 48 (1997), pp. 1042-1047

[102] M. Hersen, A.M. Gross. Handbook of Clinical Psychology. John Wiley \& Sons, New Jersey (2007)

[103]. D. Reeves, C. Blickem, I. Vassilev, H. Brooks, A. Kennedy, G. Richardson, et al. The contribution of social networks to the health and self-management of patients with longterm conditions: a longitudinal study. PLoS One, 9 (2014), pp. 1-12

[104]. J. Krieger, T.K. Takaro, L. Song, N. Beaudet, K.A. Edwards. Randomized controlled trial of asthma self-management support comparing clinic-based nurses and in-home community health workers. The Seattle-King County Healthy Homes II Project. Arch. Pediatr. Adolesc. Med., 163 (2009), pp. 141-149

[105] M. Rijken, M. Jones, M. Heijmans, A. Dixon. Supporting self-management. 
Bal, M.I., Sattoe, J.N.T., Roelofs, P.D.D.M., Bal, R., Staa, A. van, Miedema, H.S. Exploring effectiveness and effective components of self-management interventions for young people with chronic physical conditions: a systematic review. Patient Education and Counseling:2016,7 99(8), 1293-1309

E. Nolte, M. McKee (Eds.), Caring for People with Chronic Conditions. A Health System perspective, Open University Press, Berkshire (2008)

[106] S. Michie, A. Prestwich.Are interventions theory-based: development of a theory coding scheme. Health Psychol., 29 (2010), pp. 1-8

Figure AND TABLE

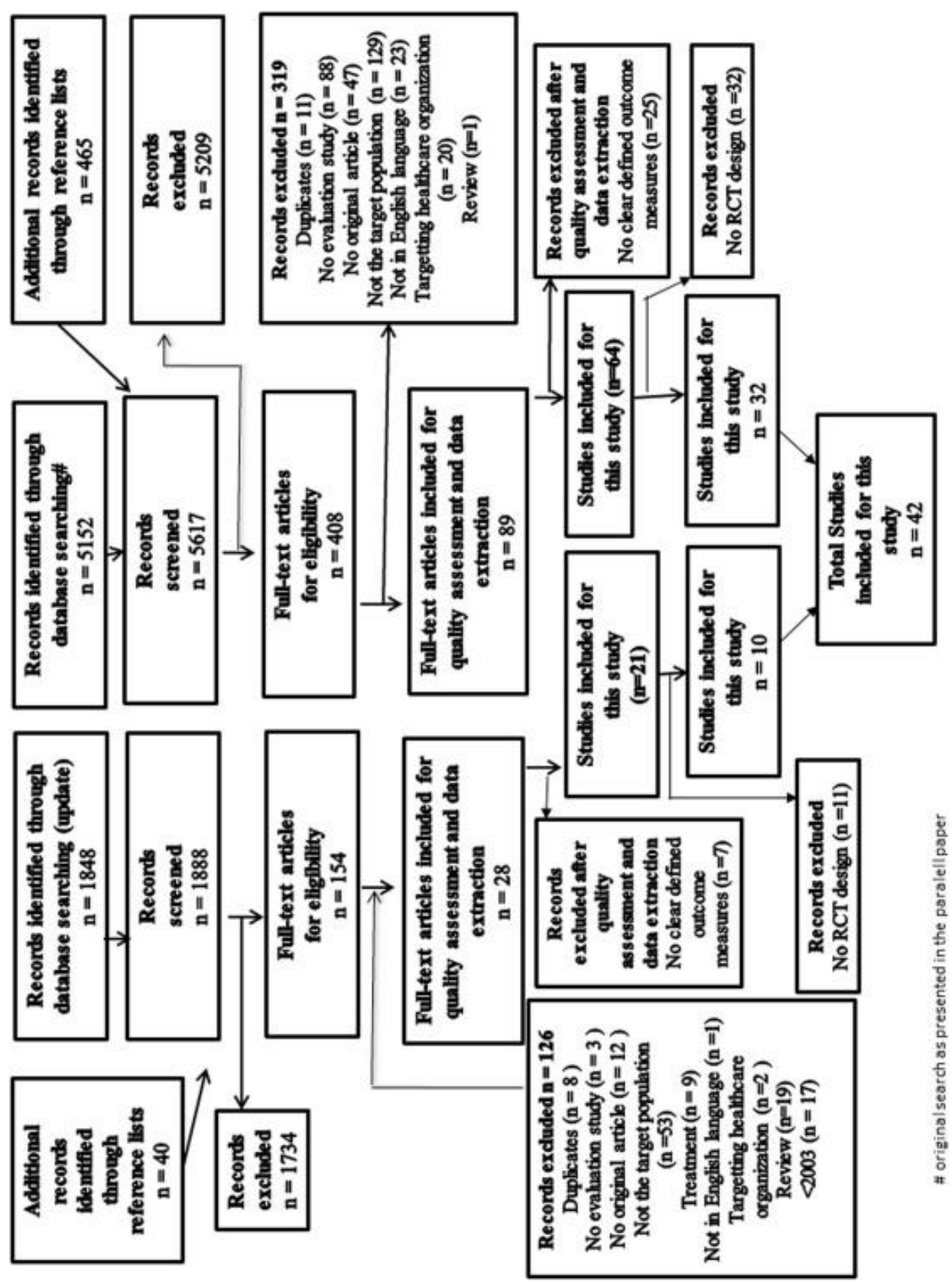


Bal, M.I., Sattoe, J.N.T., Roelofs, P.D.D.M., Bal, R., Staa, A. van, Miedema, H.S. Exploring effectiveness and effective components of self-management interventions for young people with chronic physical conditions: a systematic review. Patient Education and Counseling:2016,7 99(8), 1293-1309

Table 1. Evidence profile.

\begin{tabular}{|c|c|c|c|c|c|c|c|c|}
\hline \multirow[b]{2}{*}{$\begin{array}{c}\text { Outcome (no. } \\
\text { of studies) }\end{array}$} & \multicolumn{5}{|c|}{ Quality assessment } & \multicolumn{2}{|c|}{\begin{tabular}{|c|}
$\begin{array}{c}\text { Number } \\
\text { of } \\
\text { patients }\end{array}$ \\
\end{tabular}} & \multirow[t]{2}{*}{$\begin{array}{c}\text { Quality } \\
\text { of the } \\
\text { evidence }\end{array}$} \\
\hline & $\begin{array}{l}\text { Limitation } \\
\text { in design }\end{array}$ & Inconsistency & Indirectness & Imprecision & $\begin{array}{c}\text { Publication } \\
\text { bias }\end{array}$ & $\mathbf{C}^{\mathbf{a}}$ & $\mathbf{I}^{\mathbf{b}}$ & \\
\hline $\begin{array}{c}\text { Symptoms } \\
\text { (24) }\end{array}$ & $\begin{array}{l}\text { No serious } \\
\text { limitation }\end{array}$ & $\begin{array}{l}\text { Serious } \\
\text { inconsistency }\end{array}$ & $\begin{array}{l}\text { No serious } \\
\text { indirectness }\end{array}$ & $\begin{array}{l}\text { Very serious } \\
\text { imprecision }\end{array}$ & Unlikely & 1019 & 1085 & Very low \\
\hline $\begin{array}{c}\text { Disease } \\
\text { knowledge } \\
\text { (19) }\end{array}$ & $\begin{array}{l}\text { No serious } \\
\text { limitation }\end{array}$ & $\begin{array}{l}\text { Serious } \\
\text { inconsistency }\end{array}$ & $\begin{array}{l}\text { No serious } \\
\text { indirectness }\end{array}$ & $\begin{array}{l}\text { No serious } \\
\text { imprecision }\end{array}$ & Unlikely & 771 & 626 & Moderate \\
\hline $\begin{array}{c}\text { Adherence } \\
\text { (9) }\end{array}$ & $\begin{array}{l}\text { No serious } \\
\text { limitation }\end{array}$ & \begin{tabular}{|l} 
Serious \\
inconsistency
\end{tabular} & $\begin{array}{l}\text { No serious } \\
\text { indirectness }\end{array}$ & $\begin{array}{l}\text { Very serious } \\
\text { imprecision }\end{array}$ & Unlikely & 333 & 387 & Very low \\
\hline $\begin{array}{l}\text { Dealing with } \\
\text { chronic } \\
\text { condition in } \\
\text { daily life (11) }\end{array}$ & $\begin{array}{l}\text { No serious } \\
\text { limitation }\end{array}$ & $\begin{array}{l}\text { Very serious } \\
\text { inconsistency }\end{array}$ & $\begin{array}{l}\text { No serious } \\
\text { indirectness }\end{array}$ & $\begin{array}{l}\text { Serious } \\
\text { imprecision }\end{array}$ & Unlikely & 395 & 535 & Very low \\
\hline $\begin{array}{l}\text { Psychological } \\
\text { outcomes (9) }\end{array}$ & $\begin{array}{l}\text { No serious } \\
\text { limitation }\end{array}$ & $\begin{array}{l}\text { Serious } \\
\text { inconsistency }\end{array}$ & $\begin{array}{l}\text { No serious } \\
\text { indirectness }\end{array}$ & $\begin{array}{l}\text { Very serious } \\
\text { imprecision }\end{array}$ & Unlikely & 367 & 378 & Very low \\
\hline $\begin{array}{c}\text { School } \\
\text { attendance } \\
\text { (5) }\end{array}$ & $\begin{array}{l}\text { Serious } \\
\text { limitation }\end{array}$ & $\begin{array}{l}\text { Serious } \\
\text { inconsistency }\end{array}$ & $\begin{array}{l}\text { Very serious } \\
\text { indirectness }\end{array}$ & $\begin{array}{l}\text { No serious } \\
\text { imprecision }\end{array}$ & Unlikely & 305 & 285 & Very low \\
\hline $\begin{array}{c}\text { Quality of life } \\
\text { (13) }\end{array}$ & $\begin{array}{l}\text { No serious } \\
\text { limitation }\end{array}$ & $\begin{array}{l}\text { No serious } \\
\text { inconsistency }\end{array}$ & $\begin{array}{l}\text { No serious } \\
\text { indirectness }\end{array}$ & $\begin{array}{l}\text { No serious } \\
\text { imprecision }\end{array}$ & Unlikely & 705 & 757 & High \\
\hline
\end{tabular}

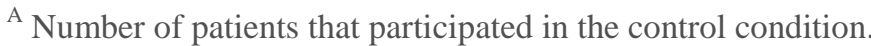

${ }^{B}$ Number of patients that participated in the intervention condition. 
Bal, M.I., Sattoe, J.N.T., Roelofs, P.D.D.M., Bal, R., Staa, A. van, Miedema, H.S. Exploring effectiveness and effective components of self-management interventions for young people with chronic physical conditions: a systematic review. Patient Education and Counseling:2016,7 99(8), 1293-1309

Fig. 2. (A) Effectiveness of intervention component domain of self-management and format on symptom reduction. (B) Effectiveness of intervention component discipline and setting on symptom reduction. (C) Effectiveness of intervention component interventionists on symptom reduction.

A

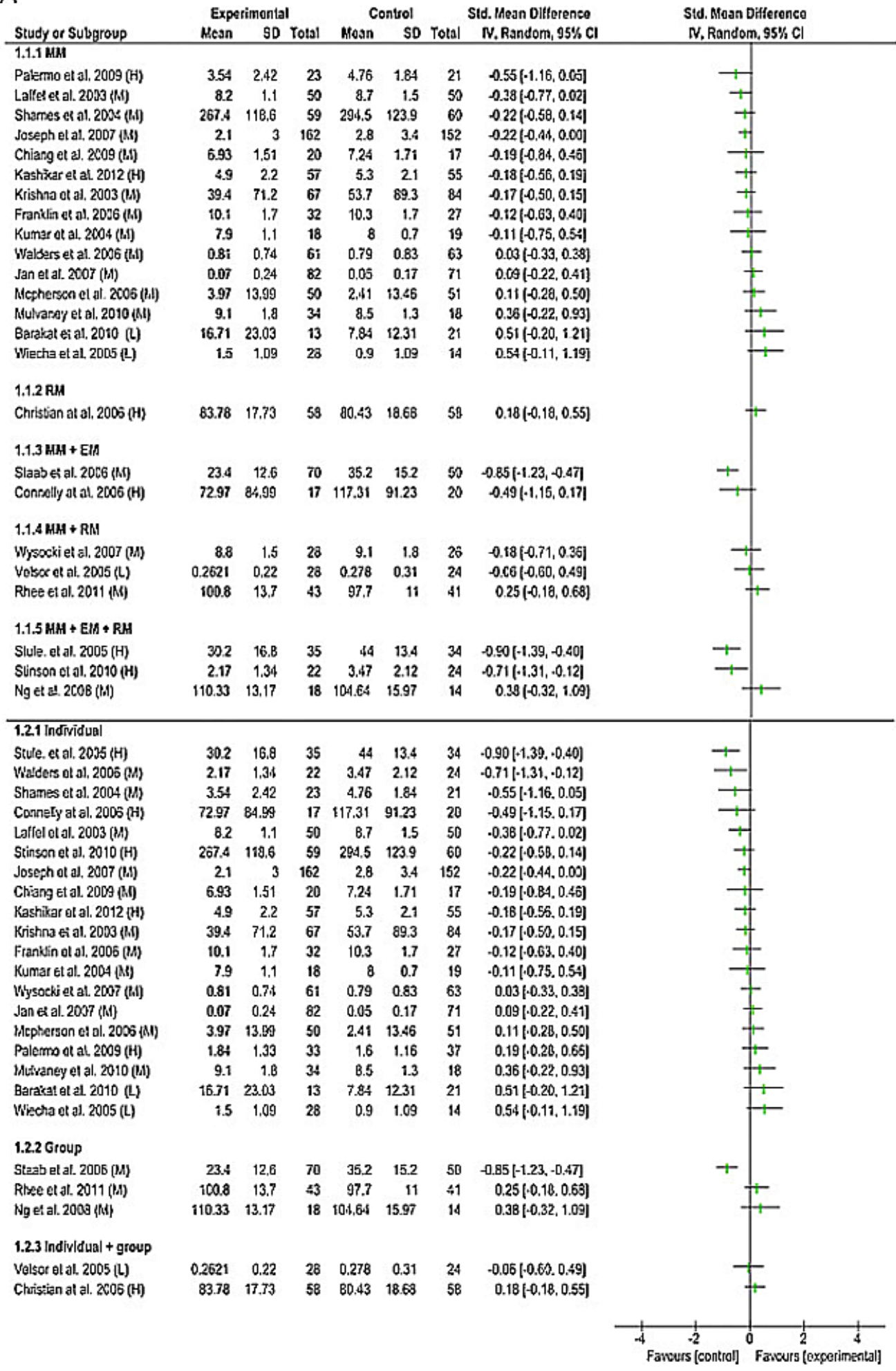


Bal, M.I., Sattoe, J.N.T., Roelofs, P.D.D.M., Bal, R., Staa, A. van, Miedema, H.S. Exploring effectiveness and effective components of self-management interventions for young people with chronic physical conditions: a systematic review. Patient Education and Counseling:2016,7 99(8), 1293-1309

B

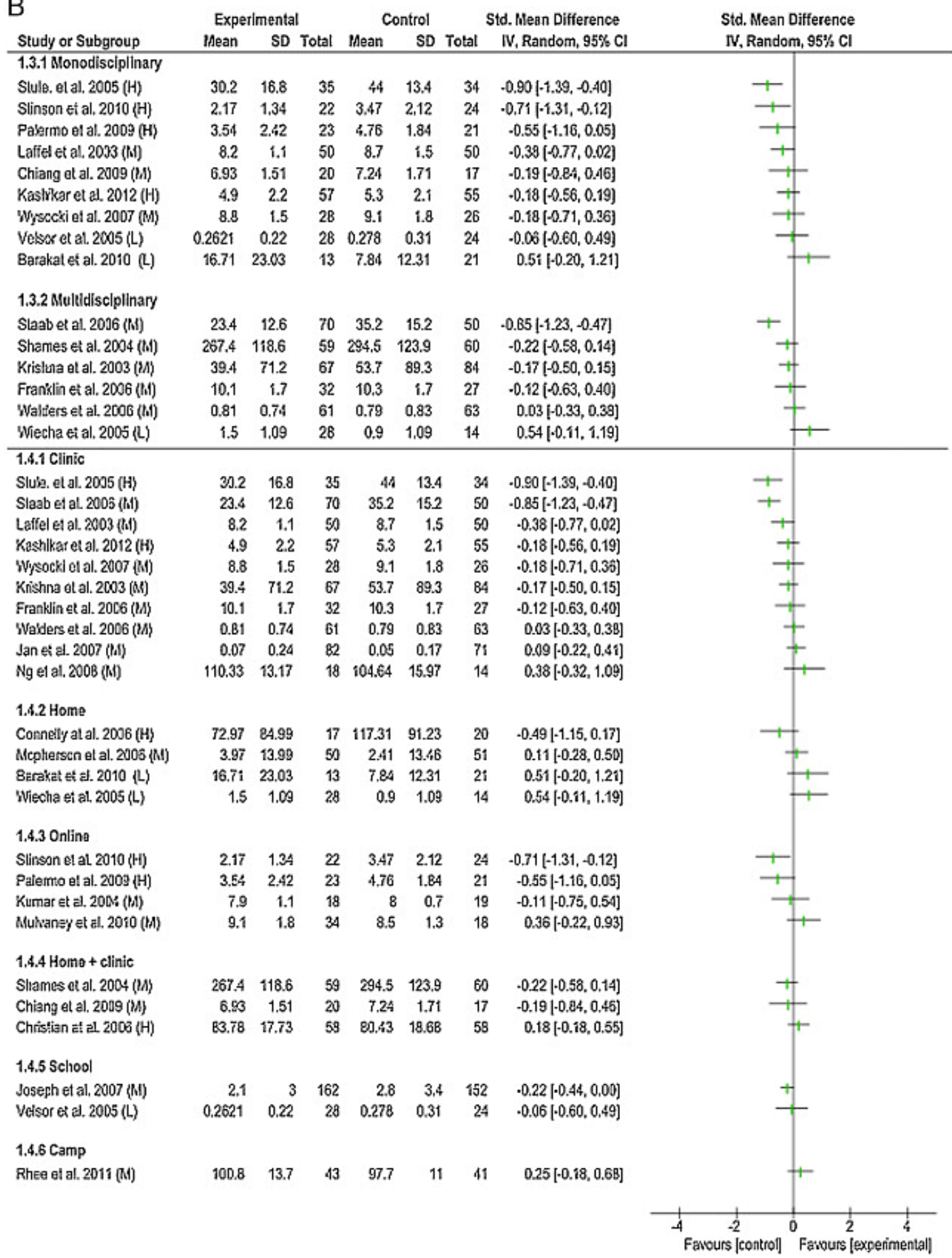


Bal, M.I., Sattoe, J.N.T., Roelofs, P.D.D.M., Bal, R., Staa, A. van, Miedema, H.S. Exploring effectiveness and effective components of self-management interventions for young people with chronic physical conditions: a systematic review. Patient Education and Counseling:2016,7 99(8), 1293-1309

Fig. 3. (A) Effectiveness of intervention component domain of self-management and format on disease knowledge. (B) Effectiveness of intervention component discipline and setting on disease knowledge.

A

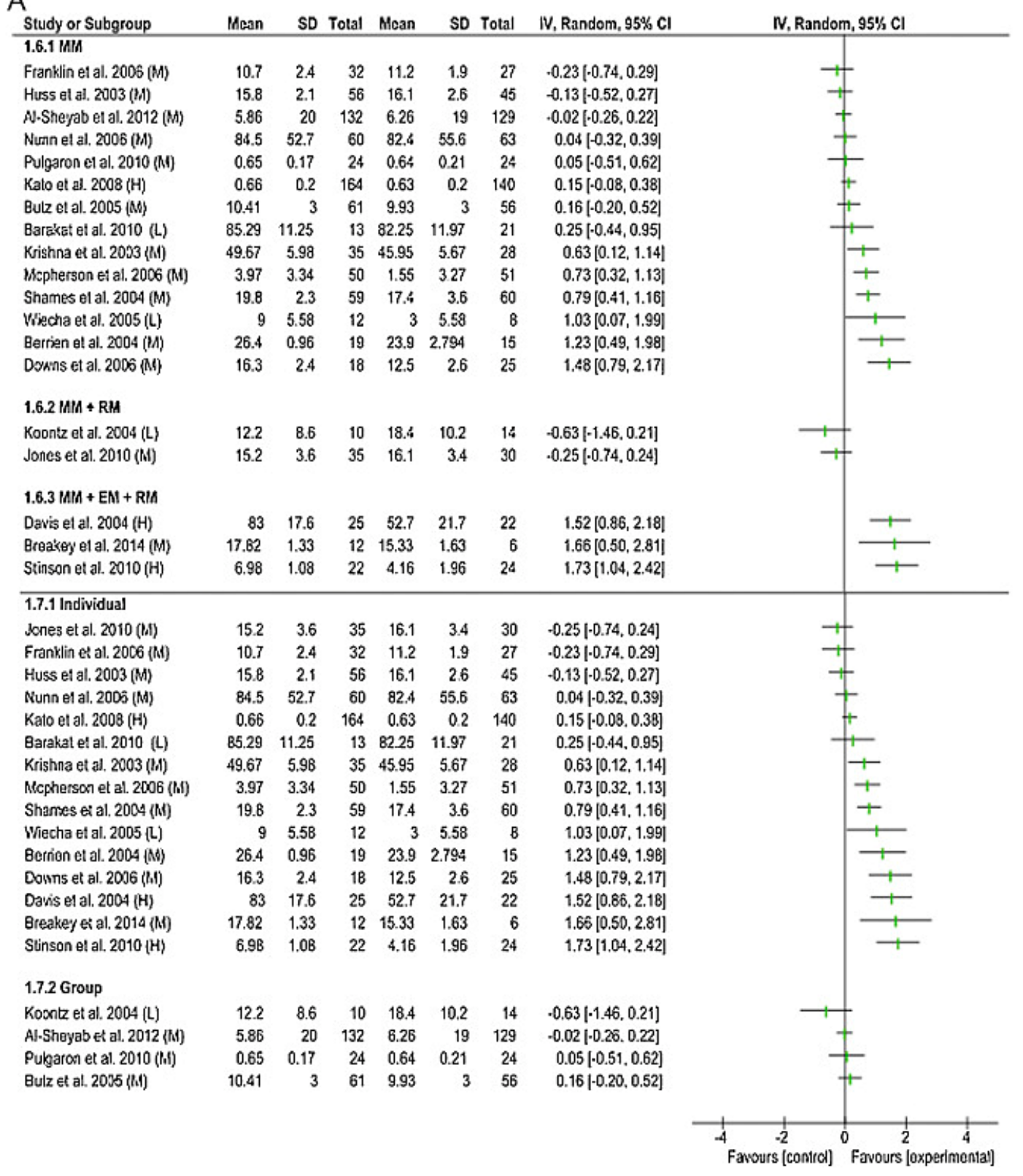


Bal, M.I., Sattoe, J.N.T., Roelofs, P.D.D.M., Bal, R., Staa, A. van, Miedema, H.S. Exploring effectiveness and effective components of self-management interventions for young people with chronic physical conditions: a systematic review. Patient Education and Counseling:2016,7 99(8), 1293-1309

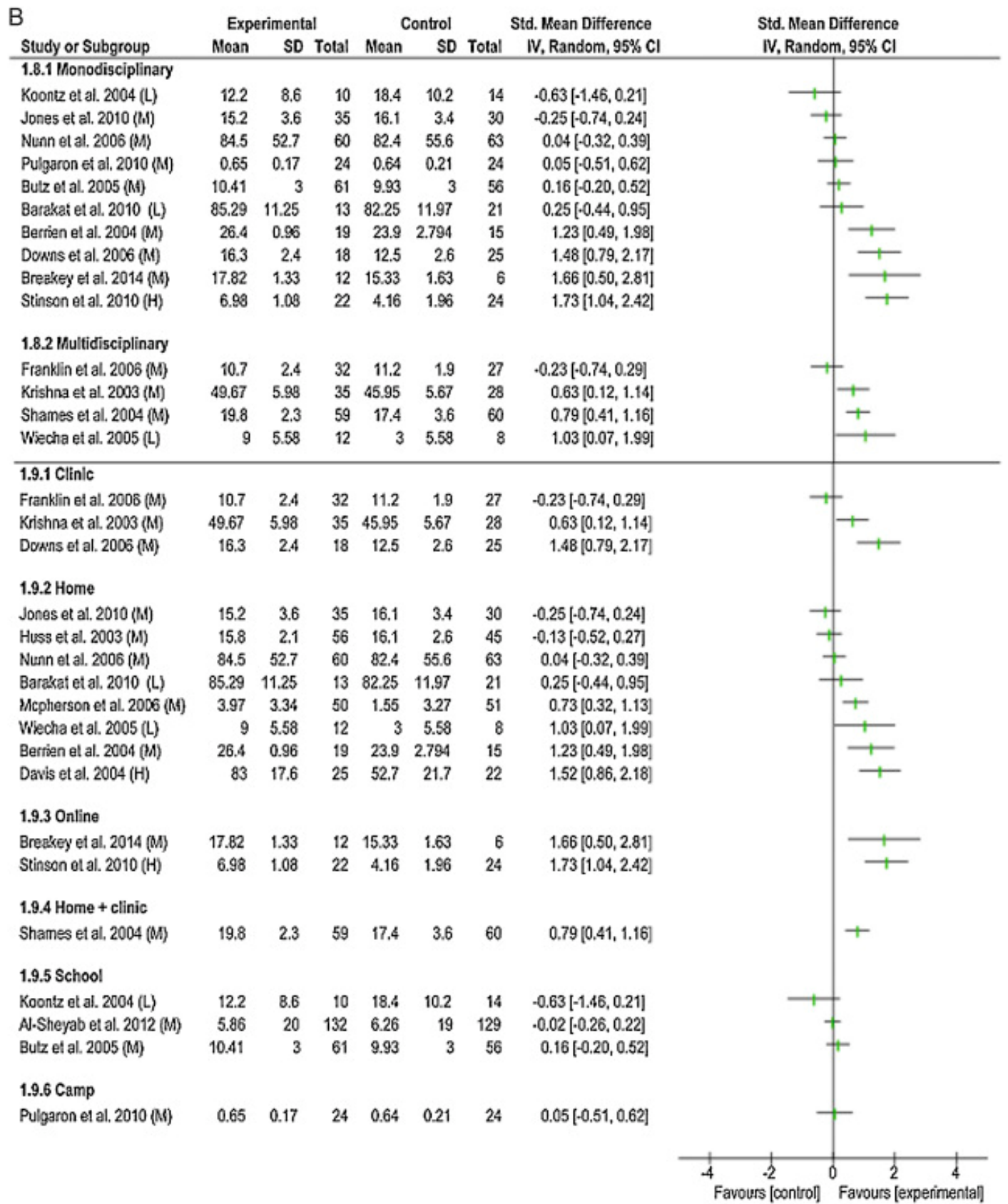


Bal, M.I., Sattoe, J.N.T., Roelofs, P.D.D.M., Bal, R., Staa, A. van, Miedema, H.S. Exploring effectiveness and effective components of self-management interventions for young people with chronic physical conditions: a systematic review. Patient Education and Counseling:2016,7 99(8), 1293-1309

Fig. 4. (A) Effectiveness of intervention component domain of self-management and format on adherence. (B) Effectiveness of intervention component discipline and setting on adherence.

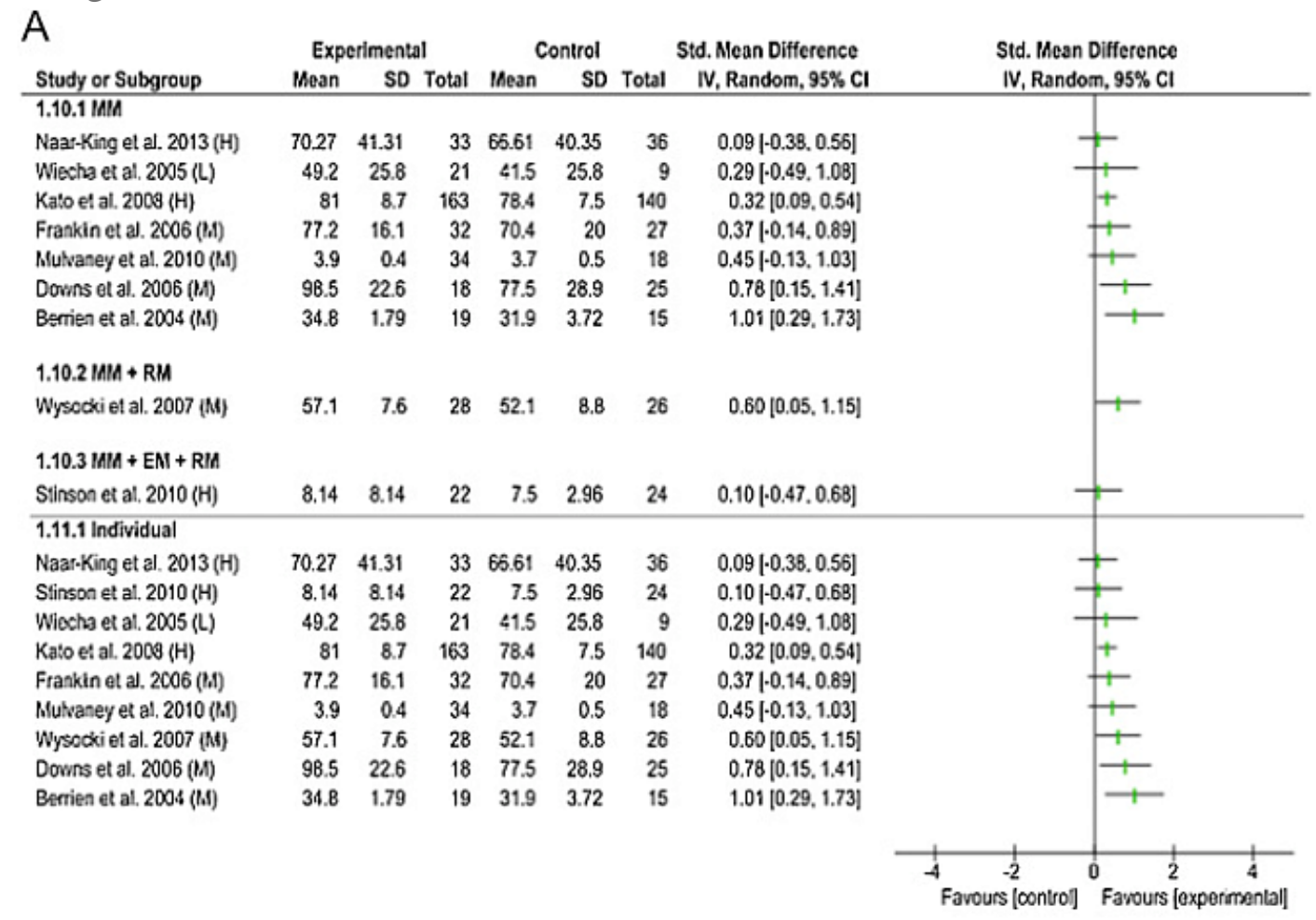

B

\begin{tabular}{|c|c|c|c|c|c|c|c|c|}
\hline \multirow[b]{2}{*}{ Study or Subgroup } & \multicolumn{3}{|c|}{ Exporimontal } & \multicolumn{3}{|c|}{ Control } & \multirow{2}{*}{$\begin{array}{l}\text { Sid. Mean Differenco } \\
\text { N, Random, } 95 \% \mathrm{Cl}\end{array}$} & \multirow{2}{*}{$\begin{array}{l}\text { Std. Moan Difforonco } \\
\text { IV, Random, } 95 \% \mathrm{Cl}\end{array}$} \\
\hline & & lean SO & D Total & Mean & n SD & Total & & \\
\hline \multicolumn{9}{|l|}{ 1.12.1 Monodisciplinary } \\
\hline Stinson et al. $2010(\mathrm{H})$ & & $8.14 \quad 8.14$ & 22 & 7.5 & 52.96 & 24 & $0.10[-0.47,0.68]$ & - \\
\hline Viysockj et at. 2007 (bl) & & $57.1 \quad 7.6$ & 28 & 52.1 & 18.8 & 26 & $0.60[0.05 .1 .15]$ & + \\
\hline Daxns et al. 2006 (M) & & 93.522 .6 & 18 & 77.5 & $5 \quad 28.9$ & 25 & $0.78[0.15,1.41]$ & 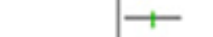 \\
\hline Bertien et al. 2004 (M) & & 34.81 .79 & 19 & 31.9 & 93.72 & 15 & $1.01[0.29 .1 .73]$ & 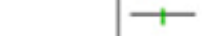 \\
\hline \multicolumn{9}{|l|}{ 1.12.2 Multidisciplinary } \\
\hline Wischa et al. 2005 (L) & & $49.2 \quad 25.8$ & 21 & 41.5 & 525.8 & 9 & $0.29[-0.49,1.08]$ & + \\
\hline Frankin et al. 2005 (M) & & 77.216 .1 & 32 & 70.4 & 420 & 27 & $0.37[-0.14,0.89]$ & + \\
\hline \multicolumn{9}{|l|}{ 1.13.1 Clinic } \\
\hline Frankin et al. $2006(M)$ & 77.2 & 16.1 & 32 & 70.4 & 20 & 27 & $0.37[-0.14,0.89]$ & + \\
\hline Wysockiet al, 2007 (M) & 57.1 & 7.6 & 28 & 52.1 & 8.8 & 26 & $0.60[0.05 .1 .15]$ & + \\
\hline Downs et al. $2006(M)$ & 98.5 & 22.6 & 18 & 77.5 & 28.9 & 25 & $0.78[0,15,1.41]$ & 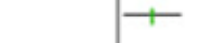 \\
\hline \multicolumn{9}{|l|}{ 1.13.2 Onlline } \\
\hline Stinson et al. $2010(\mathrm{H})$ & 8.14 & 8.14 & 22 & 7.5 & 2.96 & 24 & $0.10[-0.47,0.68]$ & - \\
\hline Mulvaney et al, $2010(\mathrm{M})$ & 3.9 & 0.4 & 34 & 3.7 & 0.5 & 18 & $0.45[\cdot 0.13 .1 .03]$ & H \\
\hline \multicolumn{9}{|c|}{$1.13 .3 \mathrm{Home}$} \\
\hline Naar-King et al. $2013(\mathrm{H})$ & 0.27 & 41.31 & 33 & 66.61 & 40.35 & 36 & $0.09[-0.38,0.56]$ & - \\
\hline Wiocha et al. $2005(\mathrm{~L})$ & 49.2 & 25.8 & 21 & 41.5 & 25.8 & 9 & $0.29[\cdot 0.49 .1 .08]$ & + \\
\hline \multirow[t]{2}{*}{ Berrien et al. $2004(\mathrm{Ml})$} & 34.8 & 1.79 & 19 & 31.9 & 3.72 & 15 & $1.01[0.29 .1 .73]$ & $一$ \\
\hline & & & & & & & & $-2{ }^{1}{ }^{1}{ }^{2}$ \\
\hline
\end{tabular}


Bal, M.I., Sattoe, J.N.T., Roelofs, P.D.D.M., Bal, R., Staa, A. van, Miedema, H.S. Exploring effectiveness and effective components of self-management interventions for young people with chronic physical conditions: a systematic review. Patient Education and Counseling 2016,7 99(8), 1293-1309

Fig. 5. (A) Effectiveness of intervention component domain of self-management and format on dealing with a chronic condition in daily life. (B) Effectiveness of intervention component discipline and setting on dealing with a chronic condition in daily life.

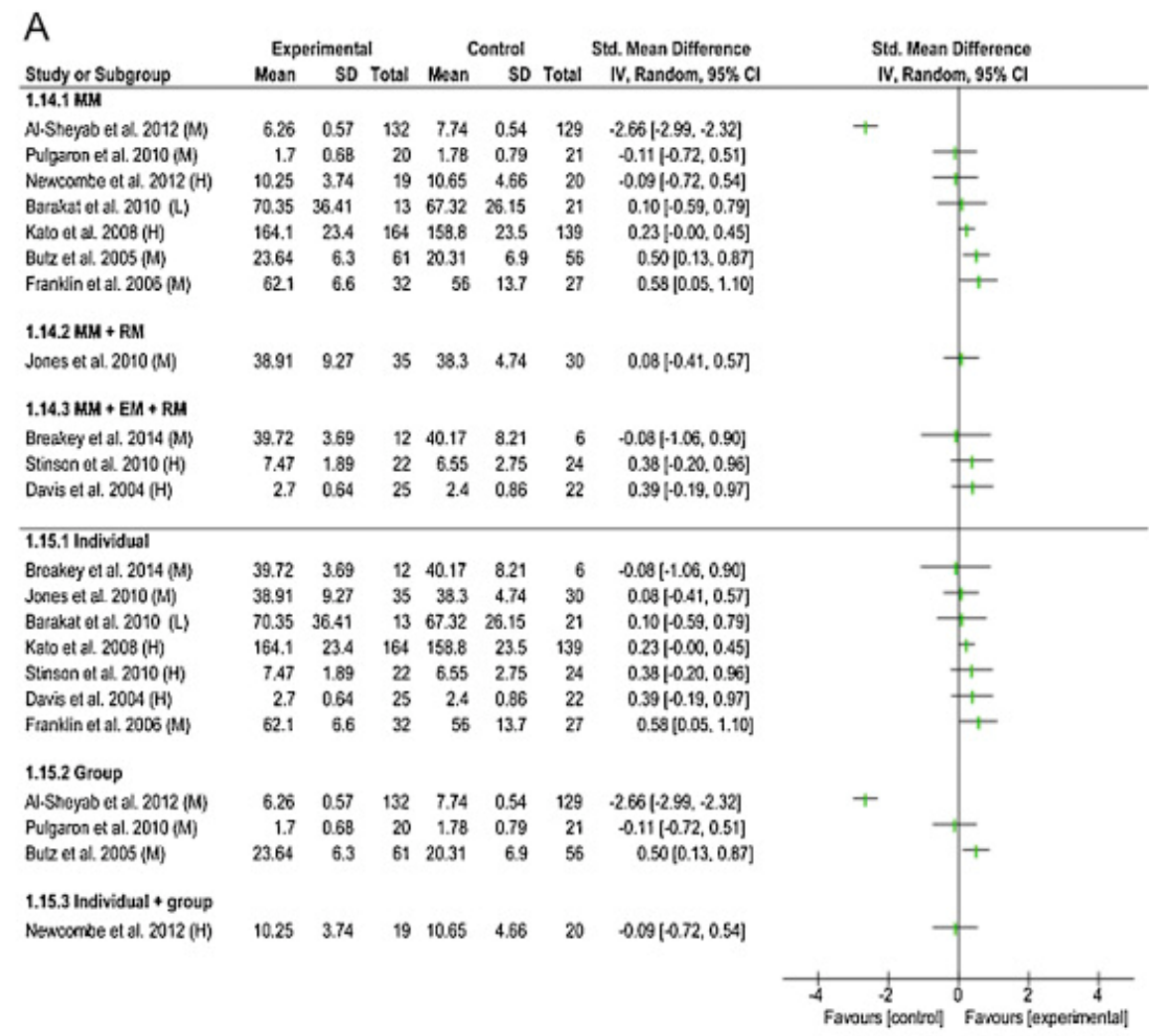

B

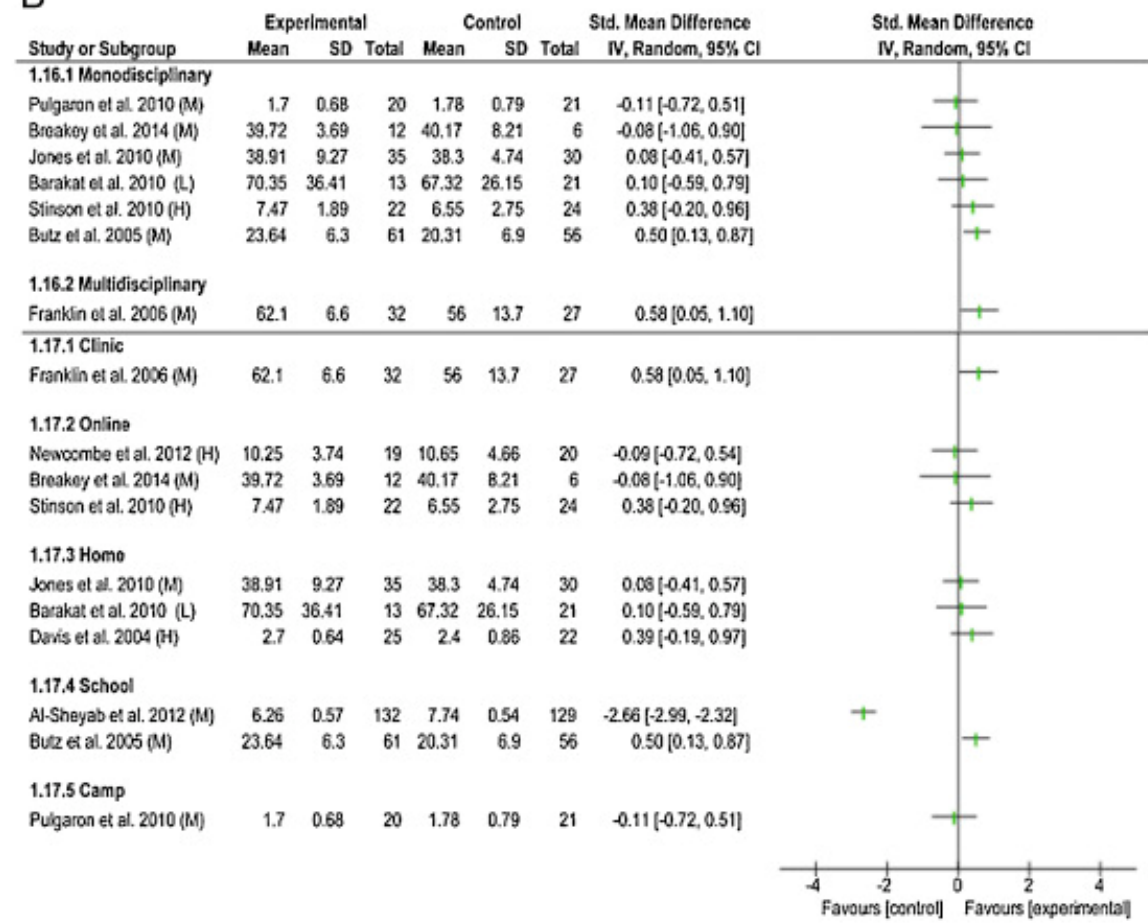


Bal, M.I., Sattoe, J.N.T., Roelofs, P.D.D.M., Bal, R., Staa, A. van, Miedema, H.S. Exploring effectiveness and effective components of self-management interventions for young people with chronic physical conditions: a systematic review. Patient Education and Counseling:2016,7 99(8), 1293-1309

Fig. 6. (A) Effectiveness of intervention component domain of self-management and format on psychological outcomes. (B) Effectiveness of intervention component discipline and setting on psychological outcomes. (C) Effectiveness of intervention component interventionists on psychological outcomes.

\begin{tabular}{|c|c|c|c|c|c|c|c|c|}
\hline \multirow{3}{*}{$\begin{array}{l}\mathrm{A} \\
\text { Stuty or Subgroup } \\
1.18 .2 \mathrm{MM}\end{array}$} & \multicolumn{3}{|c|}{ Experimenta! } & \multicolumn{3}{|c|}{ Control } & \multirow{2}{*}{$\begin{array}{l}\text { Std. Mean Difforence } \\
\text { I N, Random, } 95 \% \mathrm{Cl}\end{array}$} & \multirow{2}{*}{$\begin{array}{l}\text { Std. Mean Difference } \\
\text { N. RanSom, 95\% Cl }\end{array}$} \\
\hline & Noan & so & Tetal & Mean & So & Total & & \\
\hline & & & & & & & & \\
\hline Newocente et al. $2012(H)$ & 953 & 7.54 & 19 & 17.09 & 1324 & 20 & $.0 .68[-1.33,-0.03]$ & I \\
\hline Chianget al. 2009 (I.I) & 26.11 & 11.41 & 18 & 32.21 & 17.76 & 19 & $0.20[-1.05,0.25]$ & 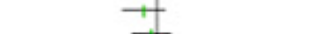 \\
\hline Pakrme ot al. 2009 (H) & 58.96 & 13.1 & 23 & 61.59 & 18.67 & 22 & $0.16[0.75,0.42]$ & \\
\hline Kashilar et al. $2012(\mathrm{H})$ & 8.7 & 6.1 & 57 & 9.3 & 59 & 55 & $0.10[-0.47,0.27)$ & \\
\hline Kalo ef a. 2008 (H) & 39.1 & 69 & 163 & 35.7 & 62 & 139 & $0.36[0.14,0.59\}$ & + \\
\hline \multicolumn{9}{|l|}{$1.18 .3 \mathrm{mM}+\mathrm{EM}$} \\
\hline Beebe et al. 2010 & 11.56 & 13.16 & 11 & 7,6 & 18.66 & 11 & $0.24[0.60,1.09)$ & + \\
\hline \multicolumn{9}{|l|}{$1.18 .4 \mathrm{MM}+\mathrm{RM}$} \\
\hline Betz ex al $2010(\mathrm{C})$ & 85.7 & 11.98 & 31 & 84,41 & $11 . n$ & 34 & $0.11(0.38,0.59)$ & - \\
\hline \multicolumn{9}{|l|}{$1.18 .5 \mathrm{MM}+\mathrm{EM}+\mathrm{RMM}$} \\
\hline Stroson ef al. $2010(\mathrm{H})$ & 198 & 0.42 & 2 & 2.13 & 0.42 & 24 & $-0.35[-0.93,0.23]$ & - \\
\hline Schoten et a. 2013 (M) & 6.35 & 5.55 & 34 & 6.91 & 6.13 & 43 & $20.09[-0.54,0.36]$ & t \\
\hline \multicolumn{9}{|l|}{ 1.19.1 hidividual } \\
\hline Criamg et al. 2009 (M) & 26.11 & 11.41 & 18 & 32.21 & 17.76 & 19 & $-0.40[-1.06,0.25]$ & $\rightarrow$ \\
\hline Stinsonel al. $2010(\mathrm{H})$ & 1.95 & 0.42 & 22 & 2.13 & $3 \quad 0.42$ & 24 & $-0.35[-0.93,0.23]$ & $\rightarrow$ \\
\hline Palsme et al. 2009 (H) & 58.96 & 13.1 & 23 & 61.59 & 18.67 & 22 & $-0.16[0.75,0.42]$ & \\
\hline Kashilar ef al. $2012(\mathrm{H})$ & 8.7 & 6.1 & 57 & 9.3 & 5.9 & 55 & $-0.10[-0.47,0.27]$ & \\
\hline Kato of at. 2008 (H) & 38.1 & 69 & 163 & 357 & 62 & 139 & $0.36(0.14,0.59)$ & + \\
\hline \multicolumn{9}{|l|}{1.19 .2 Groep } \\
\hline Sthaten et al. 2013 (M) & 6.35 & 5.55 & 34 & 691 & 6.13 & 43 & $-0.09[-0.54,0.36]$ & 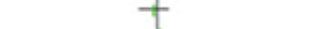 \\
\hline Betzelat 2010 (L) & 25.7 & 11.98 & 31 & 84.41 & $11 . \pi$ & 34 & $0.11(-0.38,0.59)$ & \\
\hline Betbe et at: 2010 & 11.56 & 13.16 & 11 & 7.6 & 618.66 & 11 & $0.24(-0.60,1.00)$ & \\
\hline \multicolumn{9}{|l|}{ 1.19.3 Groep + Indlvidast } \\
\hline \multirow[t]{2}{*}{ Newocombe el al, $2012(\mathrm{H})$} & 9.53 & 7.54 & 19 & 17.09 & 913.24 & 20 & $-0.58[-1.33,-0.03]$ & $T$ \\
\hline & & & & & & & & 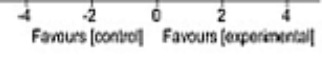 \\
\hline \multicolumn{9}{|r|}{ Std Hen Difference } \\
\hline & Expc & eriments & & & Consol & & Std. Hean Ditference & Std. Mean Difference \\
\hline Study or Sutgroup & Mean & SD & Tetal & Mean & so & Total & $\mathrm{N}$, Random, $95 \% \mathrm{Cl}$ & $\mathrm{N}$, RanSom, $95 \% \mathrm{Cl}$ \\
\hline 1.20.1 Honodisclplinary & & & & & & & & \\
\hline Chiang et al. $2009(\mathrm{M})$ & 26.11 & 11,41 & 18 & 3221 & 17.76 & 19 & $0.40[-1.05,0.25]$ & $\rightarrow$ \\
\hline Stinsen et al. 2010 (H) & 1.98 & 0.42 & 22 & 2.13 & 0.42 & 24 & $-0.35[-0.93,0.23]$ & $\rightarrow$ \\
\hline Palemo et al. $2009(\mathrm{H})$ & 58.96 & 13.1 & 23 & 61.59 & 18.67 & 22 & $-0.16[-0.75,0.42]$ & - \\
\hline Kashihar et al. $2012(\mathrm{H})$ & 8.7 & 6.1 & 57 & 9.3 & 5.9 & 55 & $0.10[-0.47,0.27]$ & \\
\hline Schollen of at. $2013(M)$ & 6.35 & 5.55 & 34 & 6.91 & 6.13 & 43 & $.0 .09[0.54,0.36]$ & - \\
\hline 1.21.1 Clinic & & & & & & & & \\
\hline Kastivar et al. $2012($ H $)$ & 8.7 & 6.1 & 57 & 9.3 & 59 & 55 & $-0.10[0.47,0.27]$ & \\
\hline Betz et al. 2010 (L) & 85.7 & 11.93 & 31 & 84.41 & 11.77 & 34 & $0.11-0.38,0.59]$ & \\
\hline 1.21.2 Home + clinic & & & & & & & & \\
\hline Cliang et at 2058 (IM) & 26.11 & 11.41 & 13 & 32.21 & 17.76 & 19 & $-0.40[-1.06,0.25]$ & T \\
\hline 1.21.3 Online & & & & & & & & \\
\hline Newornibe et al. $2012(\mathrm{H})$ & 9.53 & 7.54 & 19 & 17.09 & 1324 & 20 & $-0.65[-1.33,-0.03]$ & T \\
\hline Stinson ef at. $2010(\mathrm{H})$ & 1.99 & 0.42 & $n$ & 2.13 & 0.42 & 24 & $-0.35[-0.93,0.23)$ & $\rightarrow$ \\
\hline Palterto of al. $2009(\mathrm{Hi})$ & 58.96 & 13.1 & 23 & 61.59 & 18.67 & 22 & $-0.16[-0.75,0.42]$ & T5 \\
\hline 1.21 .4 School & & & & & & & & \\
\hline Beebe et al. 2010 & 11.56 & 13.16 & 11 & 7.6 & 1866 & 11 & $0.24[-0.60,1.05]$ & + \\
\hline 1.21.5 Clinic + school & & & & & & & & \\
\hline Schoton et al. $2013(09)$ & 6.35 & 5.55 & 34 & 6.91 & 6.13 & 43 & $.009[0.54,0.26]$ & † \\
\hline & & & & & & & & $\begin{array}{lllll}4 & -2 & 0 & 2 & 4 \\
\text { Favours |ocolvol] Faveurs [exporinental] }\end{array}$ \\
\hline C & & & & & & & & \\
\hline Study or Subgroup & & ieriments & & & Control & Total & $\begin{array}{l}\text { Std. Mean Difference } \\
\text { IV, Random, 95\% CI }\end{array}$ & $\begin{array}{l}\text { Std. Mean Difference } \\
\text { N. Random, } 95 \% \mathrm{Cl}\end{array}$ \\
\hline 1.22.1 Psychologist & Mean & SD & Total & Mean & So & & & \\
\hline Stinton et al. $2010(H)$ & 1.98 & 0.42 & 22 & 2.13 & 0.42 & 24 & $-0.35[-0.93,0.23]$ & T \\
\hline Palemto of al. $2009(\mathrm{H})$ & 53.96 & 13.1 & 23 & 61.59 & 18.57 & 22 & $-0.16[-0.75,0.42]$ & + \\
\hline Kashiar et at. $2012(H)$ & 8.7 & 6.1 & 57 & 9.3 & 59 & 55 & $-0,10-0.47,0.27]$ & f \\
\hline Schoten et al. $2013(\mathrm{M})$ & 6.35 & 5.55 & 34 & 6.91 & 6.13 & 43 & $-0.09[-0.54,0.36]$ & - \\
\hline 1.222 Nerse & & & & & & & & \\
\hline Chiam es at. $20 \% 9(M)$ & 26.11 & 11.41 & 18 & 32.21 & 17.76 & 19 & $-0.40[-1.05,0.25]$ & T \\
\hline & & & & & & & & 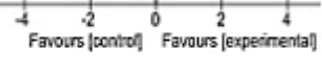 \\
\hline
\end{tabular}


Bal, M.I., Sattoe, J.N.T., Roelofs, P.D.D.M., Bal, R., Staa, A. van, Miedema, H.S. Exploring effectiveness and effective components of self-management interventions for young people with chronic physical conditions: a systematic review. Patient Education and Counseling 2016,7 99(8), 1293-1309

Fig. 7. Effectiveness of intervention component domain of self-management on quality of life.

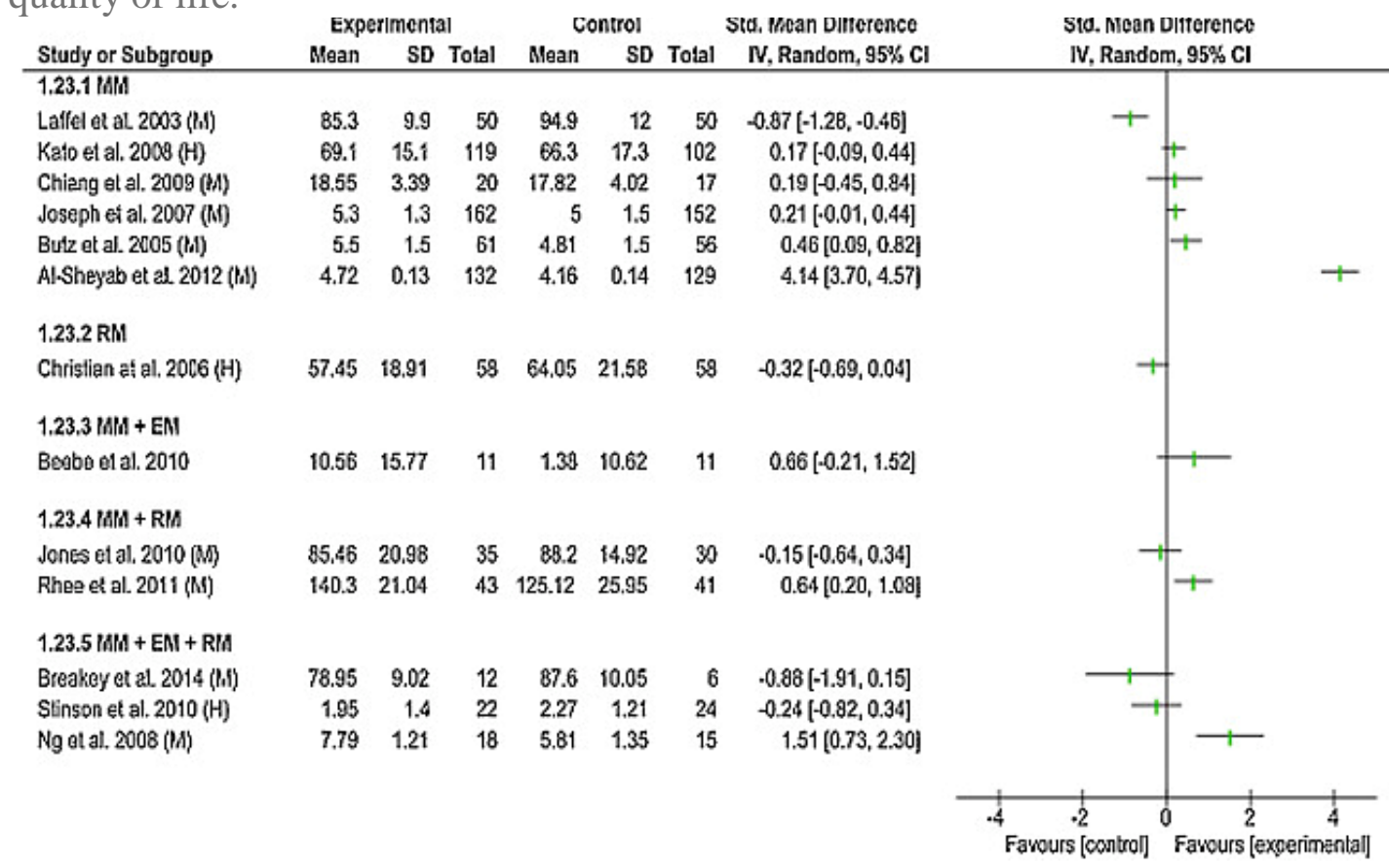


Appendix A. Study characteristics and intervention components

\begin{tabular}{|c|c|c|c|c|c|c|c|c|c|c|c|c|}
\hline \multicolumn{2}{|c|}{ Background } & \multicolumn{2}{|c|}{ Participants } & \multicolumn{3}{|c|}{ Study characteristics } & \multicolumn{6}{|c|}{ Components of self-management interventions } \\
\hline Studies: & 总 & 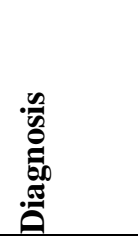 & $\mathbf{Z}$ & 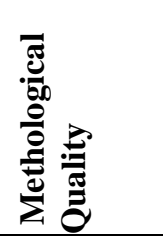 & 苞 & 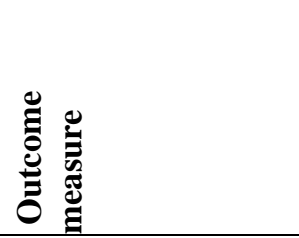 & 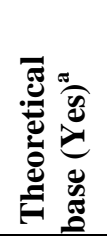 & 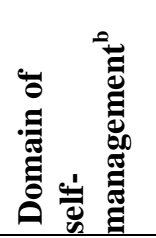 & 苞 & $\stackrel{0}{\stackrel{0}{0}}$ & 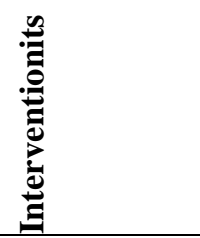 & : \\
\hline $\begin{array}{l}\text { Al-Sheyab } \\
\text { et al. } 2012 \\
{[42]}\end{array}$ & $\begin{array}{l}\text { Jordan } \\
\text { Australia }\end{array}$ & Asthma & $\begin{array}{l}N=261 \\
I=132 \\
C=129\end{array}$ & Moderate & $\begin{array}{l}\text { Usual } \\
\text { care }\end{array}$ & $\begin{array}{l}\text { Disease knowledge } \\
\text { Quality of life } \\
\text { Dealing with the } \\
\text { chronic condition in } \\
\text { daily life }\end{array}$ & NA & $\mathrm{MM}$ & Group & $\begin{array}{l}\text { Education } \\
\text { Discussion } \\
\text { Problem- } \\
\text { solving skills }\end{array}$ & Peers & School \\
\hline $\begin{array}{l}\text { Barakat et } \\
\text { al. } 2010 \\
{[43]}\end{array}$ & USA & $\begin{array}{l}\text { Sickle } \\
\text { cell } \\
\text { disease }\end{array}$ & $\begin{array}{l}\mathrm{N}=37 \\
\mathrm{I}=17 \\
\mathrm{C}=20\end{array}$ & Low & $\begin{array}{l}\text { Another } \\
\text { specific } \\
\text { inter- } \\
\text { vention }\end{array}$ & $\begin{array}{l}\text { Symptoms } \\
\text { Dealing with the } \\
\text { chronic condition in } \\
\text { daily life } \\
\text { School attendance } \\
\text { Disease knowledge }\end{array}$ & NA & MM & Individual & $\begin{array}{l}\text { Education } \\
\text { Cognitive } \\
\text { restructuring } \\
\text { Self- } \\
\text { monitoring } \\
\text { Relaxation } \\
\text { training }\end{array}$ & Psychologist & Home \\
\hline $\begin{array}{l}\text { Beebe et } \\
\text { al. } 2010 \\
{[44]}\end{array}$ & USA & Asthma & $\mathrm{N}=22$ & Low & Waitlist & $\begin{array}{l}\text { Quality of life } \\
\text { Psychological } \\
\text { outcomes }\end{array}$ & NA & $\mathrm{MM}+\mathrm{EM}$ & Group & Art-therapy & NA & School \\
\hline $\begin{array}{l}\text { Berrien et } \\
\text { al. } 2004 \\
{[45]}\end{array}$ & USA & HIV & $\begin{array}{l}\mathrm{N}=3 \\
\mathrm{I}=20 \\
\mathrm{C}=17\end{array}$ & Moderate & $\begin{array}{l}\text { Usual } \\
\text { care }\end{array}$ & $\begin{array}{l}\text { Disease knowledge } \\
\text { Adherence }\end{array}$ & NA & MM & Individual & Education & Nurse & Home \\
\hline
\end{tabular}


Appendix A. Study characteristics and intervention components (continued)

\begin{tabular}{|c|c|c|c|c|c|c|c|c|c|c|c|c|}
\hline \multicolumn{2}{|c|}{ Background } & \multicolumn{2}{|c|}{ Participants } & \multicolumn{3}{|c|}{ Study characteristics } & \multicolumn{6}{|c|}{ Components of self-management interventions } \\
\hline Studies: & 莺 & 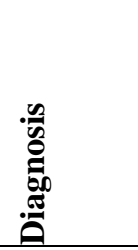 & $\mathbf{z}$ & 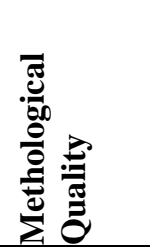 & 司 & 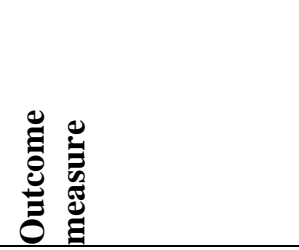 & 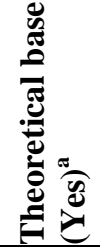 & 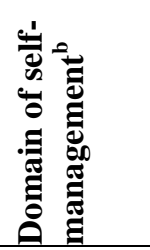 & 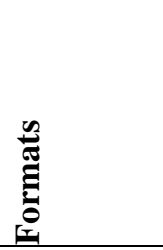 & 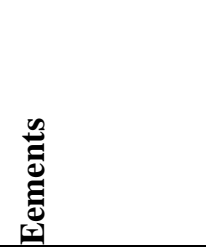 & 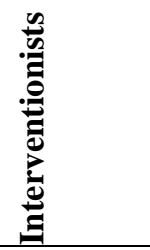 & $\stackrel{0}{: 00}$ \\
\hline $\begin{array}{l}\text { Betz et al. } \\
2010 \text { [46] }\end{array}$ & USA & $\begin{array}{l}\text { Spina } \\
\text { Bifida }\end{array}$ & $\begin{array}{l}\mathrm{N}=65 \\
\mathrm{I}=31 \\
\mathrm{C}=34\end{array}$ & Low & $\begin{array}{l}\text { Usual } \\
\text { care }\end{array}$ & $\begin{array}{l}\text { Psychological } \\
\text { outcomes }\end{array}$ & NA & $\begin{array}{l}\text { MM+ } \\
\text { RM }\end{array}$ & Group & $\begin{array}{l}\text { Goal-setting } \\
\text { skills }\end{array}$ & NA & Clinic \\
\hline $\begin{array}{l}\text { Breakey et } \\
\text { al. } 2014 \\
{[47]}\end{array}$ & Canada & $\begin{array}{l}\text { Haemop } \\
\text { hilia }\end{array}$ & $\begin{array}{l}N=29 \\
I=16 \\
C=13\end{array}$ & Moderate & $\begin{array}{l}\text { Usual } \\
\text { care }\end{array}$ & $\begin{array}{l}\text { Quality of life } \\
\text { Dealing with the } \\
\text { chronic condition in } \\
\text { daily life } \\
\text { Disease knowledge }\end{array}$ & NA & $\begin{array}{l}\mathrm{MM}+ \\
\mathrm{EM}+\mathrm{RM}\end{array}$ & Individual & $\begin{array}{l}\text { Education } \\
\text { Relaxation } \\
\text { training } \\
\text { Peer-support } \\
\text { Telemedicine }\end{array}$ & $\begin{array}{l}\text { Research } \\
\text { assistant }\end{array}$ & Online \\
\hline $\begin{array}{l}\text { Butz et al. } \\
2005 \text { [48] }\end{array}$ & USA & Asthma & $\begin{array}{l}N=200 \\
I=112 \\
C=98\end{array}$ & Moderate & $\begin{array}{l}\text { Usual } \\
\text { care }\end{array}$ & $\begin{array}{l}\text { Quality of life } \\
\text { Dealing with the } \\
\text { chronic condition in } \\
\text { daily life } \\
\text { Disease knowledge }\end{array}$ & NA & MM & Group & Education & $\begin{array}{l}\text { Asthma } \\
\text { educator }\end{array}$ & School \\
\hline
\end{tabular}


Appendix A. Study characteristics and intervention components (continued)

\begin{tabular}{|c|c|c|c|c|c|c|c|c|c|c|c|c|}
\hline \multicolumn{2}{|c|}{ Background } & \multicolumn{2}{|c|}{ Participants } & \multicolumn{3}{|c|}{ Study characteristics } & \multicolumn{6}{|c|}{ Components of self-management interventions } \\
\hline Studies: & 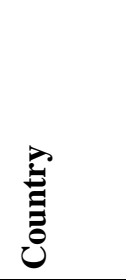 & 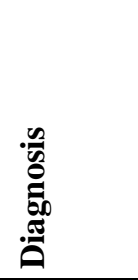 & $\mathbf{Z}$ & 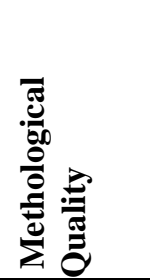 & i் & 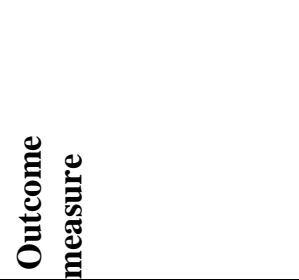 & 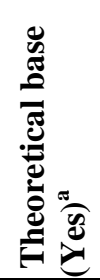 & 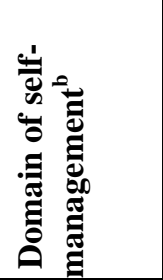 & 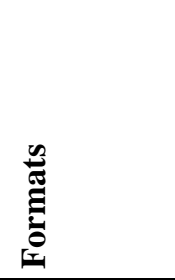 & $\underset{\frac{0}{0}}{\stackrel{0}{0}}$ & 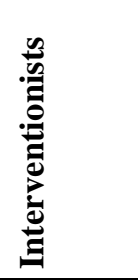 & : \\
\hline $\begin{array}{l}\text { Chiang et } \\
\text { al. } 2009 \\
{[49]}\end{array}$ & Taiwan & Asthma & $\begin{array}{l}N=48 \\
I=22 \\
C=26\end{array}$ & Moderate & $\begin{array}{l}\text { Another } \\
\text { specific } \\
\text { inter- } \\
\text { vention }\end{array}$ & $\begin{array}{l}\text { Quality of life } \\
\text { Symptoms } \\
\text { Psychological } \\
\text { outcomes }\end{array}$ & NA & $\mathrm{MM}$ & Individual & $\begin{array}{l}\text { Education } \\
\begin{array}{l}\text { Self- } \\
\text { monitoring }\end{array} \\
\begin{array}{l}\text { Relaxation } \\
\text { training }\end{array}\end{array}$ & $\begin{array}{l}\text { Nurse } \\
\text { (under- } \\
\text { graduate } \\
\text { degree) }\end{array}$ & $\begin{array}{l}\text { Home } \\
\text { Clinic }\end{array}$ \\
\hline $\begin{array}{l}\text { Christian } \\
\text { et al. } 2006 \\
\text { [50] }\end{array}$ & USA & $\begin{array}{l}\text { Cystic } \\
\text { Fibrosis }\end{array}$ & $\begin{array}{l}N=116 \\
I=58 \\
C=58\end{array}$ & High & $\begin{array}{l}\text { Usual } \\
\text { care }\end{array}$ & $\begin{array}{l}\text { Quality of life } \\
\text { Symptoms }\end{array}$ & NA & RM & $\begin{array}{l}\text { Individual } \\
\text { Group }\end{array}$ & $\begin{array}{l}\text { Education } \\
\text { Problem } \\
\text { solving skills } \\
\text { Peer-support }\end{array}$ & NA & $\begin{array}{l}\text { Home } \\
\text { Clinic }\end{array}$ \\
\hline $\begin{array}{l}\text { Connelly } \\
\text { et al. } 2006 \\
{[51]}\end{array}$ & USA & $\begin{array}{l}\text { Mi- } \\
\text { graine }\end{array}$ & $\begin{array}{l}N=31 \\
I=14 \\
C=17\end{array}$ & High & Waitlist & Symptoms & NA & $\mathrm{MM}+\mathrm{EM}$ & Individual & $\begin{array}{l}\text { Education } \\
\begin{array}{l}\text { Relaxation } \\
\text { training }\end{array} \\
\text { Cognitive } \\
\text { restructuring }\end{array}$ & NA & Home \\
\hline $\begin{array}{l}\text { Davis et } \\
\text { al. } 2004 \\
{[52]}\end{array}$ & USA & $\begin{array}{l}\text { Cystic } \\
\text { Fibrosis }\end{array}$ & $\begin{array}{l}\mathrm{N}=47 \\
\mathrm{I}=25 \\
\mathrm{C}=22\end{array}$ & High & Waitlist & $\begin{array}{l}\text { Dealing with the } \\
\text { chronic condition in } \\
\text { daily life }\end{array}$ & NA & $\begin{array}{l}\mathrm{MM}+ \\
\mathrm{RM}+\mathrm{EM}\end{array}$ & Individual & Education & NA & Home \\
\hline
\end{tabular}


Appendix A. Study characteristics and intervention components (continued)

\begin{tabular}{|c|c|c|c|c|c|c|c|c|c|c|c|c|}
\hline \multicolumn{2}{|c|}{ Background } & \multicolumn{2}{|c|}{ Participants } & \multicolumn{3}{|c|}{ Study characteristics } & \multicolumn{6}{|c|}{ Components of self-management interventions } \\
\hline Studies: & 总 & 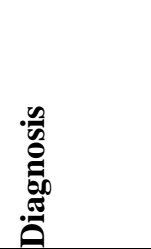 & $\mathbf{z}$ & 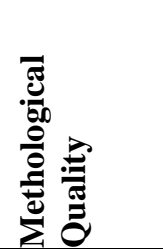 & 官 & 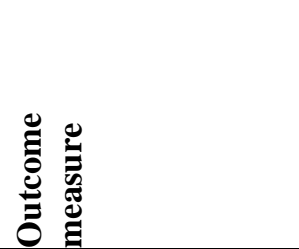 & 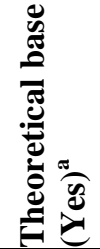 & 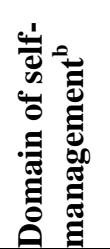 & 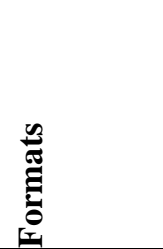 & 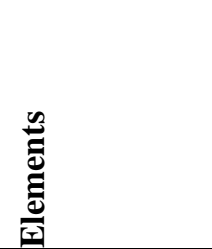 & 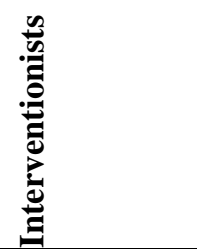 & $\stackrel{\infty}{:}$ \\
\hline $\begin{array}{l}\text { Downs et } \\
\text { al. } 2006 \\
{[53]}\end{array}$ & Australia & $\begin{array}{l}\text { Cystic } \\
\text { Fibrosis }\end{array}$ & $\begin{array}{l}\mathrm{N}=43 \\
\mathrm{I}=18 \\
\mathrm{C}=25\end{array}$ & Moderate & Not clear & $\begin{array}{l}\text { Adherence } \\
\text { Disease knowledge }\end{array}$ & CSL & $\mathrm{MM}$ & Individual & $\begin{array}{l}\text { Education } \\
\text { Problem- } \\
\text { solving skills } \\
\text { Decision- } \\
\text { making skills }\end{array}$ & $\begin{array}{l}\text { Healthcare } \\
\text { professional }\end{array}$ & Clinic \\
\hline $\begin{array}{l}\text { Franklin et } \\
\text { al. } 2006 \\
\text { [54] }\end{array}$ & UK & Diabetes & $\begin{array}{l}\mathrm{N}=90 \\
\mathrm{I} 1=32 \\
\mathrm{I} 2=31 \\
\mathrm{C}=27\end{array}$ & Moderate & $\begin{array}{l}\text { Another } \\
\text { specific } \\
\text { inter- } \\
\text { vention }\end{array}$ & $\begin{array}{l}\text { Symptoms } \\
\text { Dealing with the } \\
\text { chronic condition in } \\
\text { daily life } \\
\text { Adherence } \\
\text { Disease knowledge }\end{array}$ & CSL & MM & Individual & $\begin{array}{l}\text { Telemedicine } \\
\text { Goal-setting } \\
\text { skills }\end{array}$ & $\begin{array}{l}\text { Diabetes } \\
\text { healthcare } \\
\text { team }\end{array}$ & Clinic \\
\hline $\begin{array}{l}\text { Huss et al. } \\
2003 \text { [55] }\end{array}$ & USA & Asthma & $\begin{array}{l}N=101 \\
I=56 \\
C=45\end{array}$ & Moderate & $\begin{array}{l}\text { Usual } \\
\text { care }\end{array}$ & Disease knowledge & NA & MM & Individual & Education & NA & Home \\
\hline $\begin{array}{l}\text { Jan et al. } \\
2007[56]\end{array}$ & Taiwan & Asthma & $\begin{array}{l}N=164 \\
I=88 \\
C=76\end{array}$ & Moderate & $\begin{array}{l}\text { Another } \\
\text { specific } \\
\text { inter- } \\
\text { vention }\end{array}$ & Symptoms & NA & MM & Individual & $\begin{array}{l}\text { Education } \\
\text { Self- } \\
\text { monitoring }\end{array}$ & NA & $\begin{array}{l}\text { Clinic } \\
\text { (out- } \\
\text { patient) }\end{array}$ \\
\hline
\end{tabular}


Appendix A. Study characteristics and intervention components (continued)

\begin{tabular}{|c|c|c|c|c|c|c|c|c|c|c|c|c|}
\hline \multicolumn{2}{|c|}{ Background } & \multicolumn{2}{|c|}{ Participants } & \multicolumn{3}{|c|}{ Study characteristics } & \multicolumn{6}{|c|}{ Components of self-management interventions } \\
\hline Studies: & $\stackrel{\Xi}{\Xi}$ & 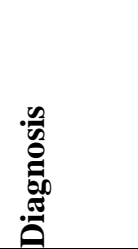 & $\mathbf{Z}$ & 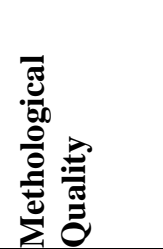 & 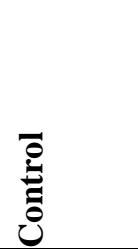 & 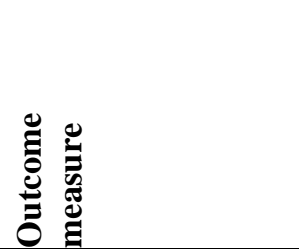 & 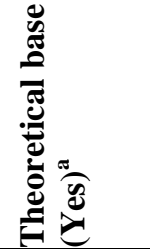 & 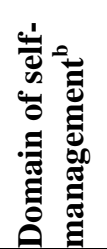 & 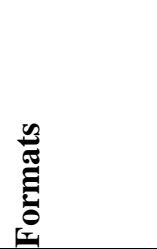 & 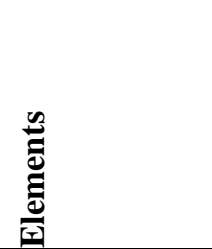 & 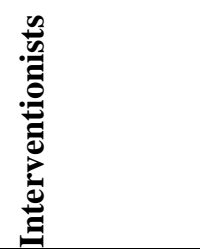 & 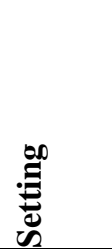 \\
\hline $\begin{array}{l}\text { Jones et al. } \\
2010 \text { [57] }\end{array}$ & USA & Cancer & $\begin{array}{l}N=65 \\
I=35 \\
C=30\end{array}$ & Moderate & $\begin{array}{l}\text { Another } \\
\text { specific } \\
\text { inter- } \\
\text { vention }\end{array}$ & $\begin{array}{l}\text { Quality of life } \\
\text { Dealing with the } \\
\text { chronic condition in } \\
\text { daily life } \\
\text { Disease knowledge }\end{array}$ & NA & $\begin{array}{l}\mathrm{MM}+ \\
\mathrm{RM}\end{array}$ & Individual & Education & $\begin{array}{l}\text { Healthcare } \\
\text { professional }\end{array}$ & Home \\
\hline $\begin{array}{l}\text { Joseph et } \\
\text { al. } 2007 \\
{[58]}\end{array}$ & USA & Asthma & $\begin{aligned} \mathrm{N} & =314 \\
\mathrm{I} & =162 \\
\mathrm{C} & =152\end{aligned}$ & Moderate & $\begin{array}{l}\text { Another } \\
\text { specific } \\
\text { inter- } \\
\text { vention }\end{array}$ & $\begin{array}{l}\text { Quality of life } \\
\text { Symptoms } \\
\text { School attendance }\end{array}$ & $\begin{array}{l}\text { Trans- } \\
\text { theoretic } \\
\text { al/Health } \\
\text { belief } \\
\text { model } \\
\end{array}$ & MM & Individual & Education & NA & School \\
\hline $\begin{array}{l}\text { Kashikar- } \\
\text { Zuck et al. } \\
2005 \text { [59] } \\
\text { Kashikar- } \\
\text { Zuck et al. } \\
2012 \text { [60] }\end{array}$ & USA & $\begin{array}{l}\text { Juvenile } \\
\text { Fibro- } \\
\text { myalgia }\end{array}$ & $\begin{array}{l}N=114 \\
I=57 \\
C=57\end{array}$ & High & $\begin{array}{l}\text { Another } \\
\text { specific } \\
\text { inter- } \\
\text { vention }\end{array}$ & $\begin{array}{l}\text { Symptoms } \\
\text { Psychological } \\
\text { outcomes }\end{array}$ & CBT & MM & Individual & $\begin{array}{l}\text { Cognitive } \\
\text { restructuring } \\
\text { Education } \\
\text { Relaxation } \\
\text { training } \\
\text { Problem- } \\
\text { solving skills }\end{array}$ & Psychologist & Clinic \\
\hline
\end{tabular}




\begin{tabular}{|c|c|c|c|c|c|c|c|c|c|c|c|c|}
\hline \multicolumn{2}{|c|}{ Background } & \multicolumn{2}{|c|}{ Participants } & \multicolumn{3}{|c|}{ Study characteristics } & \multicolumn{6}{|c|}{ Components of self-management interventions } \\
\hline Studies: & 总 & 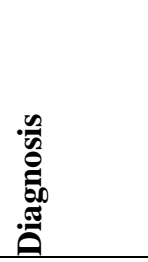 & $\mathbf{Z}$ & 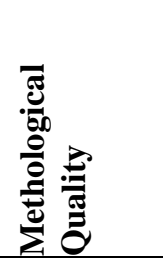 & 它 & 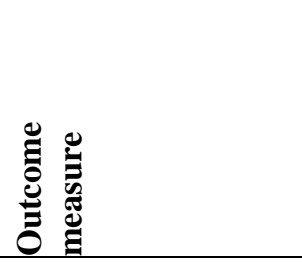 & 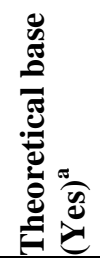 & 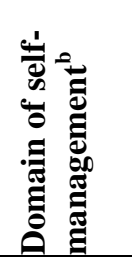 & 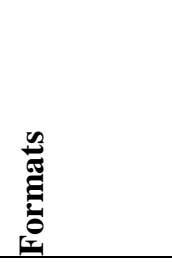 & $\underset{\frac{0}{0}}{\stackrel{0}{0}}$ & 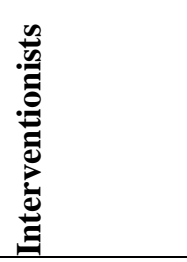 & 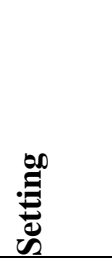 \\
\hline $\begin{array}{l}\text { Kato et al. } \\
2008 \text { [61] }\end{array}$ & USA & Cancer & $\begin{aligned} \mathrm{N} & =371 \\
\mathrm{I} & =195 \\
\mathrm{C} & =176\end{aligned}$ & High & $\begin{array}{l}\text { Another } \\
\text { specific } \\
\text { inter- } \\
\text { vention }\end{array}$ & $\begin{array}{l}\text { Quality of life } \\
\text { Dealing with the } \\
\text { chronic condition in } \\
\text { daily life } \\
\text { Psychological } \\
\text { outcomes } \\
\text { Adherence } \\
\text { Disease knowledge }\end{array}$ & CSL & MM & Individual & Education & NA & NA \\
\hline $\begin{array}{l}\text { Koontz et } \\
\text { al. } 2004 \\
{[62]}\end{array}$ & USA & $\begin{array}{l}\text { Sickle } \\
\text { cell } \\
\text { disease }\end{array}$ & $\begin{array}{l}N=24 \\
I=10 \\
C=14\end{array}$ & Low & $\begin{array}{l}\text { Another } \\
\text { specific } \\
\text { inter- } \\
\text { vention }\end{array}$ & $\begin{array}{l}\text { School attendence } \\
\text { Disease knowledge }\end{array}$ & NA & $\begin{array}{l}\mathrm{MM}+\mathrm{R} \\
\mathrm{M}\end{array}$ & Group & $\begin{array}{l}\text { Education } \\
\text { Peer-support }\end{array}$ & Teachers & School \\
\hline $\begin{array}{l}\text { Krishna et } \\
\text { al. } 2003 \\
{[63]}\end{array}$ & USA & Asthma & $\begin{array}{l}N=228 \\
I=107 \\
C=121\end{array}$ & Moderate & $\begin{array}{l}\text { Another } \\
\text { specific } \\
\text { inter- } \\
\text { vention }\end{array}$ & $\begin{array}{l}\text { Symptoms } \\
\text { School attendance } \\
\text { Disease knowledge }\end{array}$ & NA & MM & Invididual & $\begin{array}{l}\text { Education } \\
\text { Decision- } \\
\text { making skills } \\
\text { Social skills }\end{array}$ & $\begin{array}{l}\text { Multi- } \\
\text { disciplinary } \\
\text { team }\end{array}$ & Clinic \\
\hline $\begin{array}{l}\text { Kumar et } \\
\text { al. } 2004 \\
{[64]}\end{array}$ & USA & Diabetes & $\begin{array}{l}N=40 \\
I=19 \\
C=21\end{array}$ & Moderate & $\begin{array}{l}\text { Another } \\
\text { specific } \\
\text { inter- } \\
\text { vention } \\
\end{array}$ & Symptoms & NA & MM & Individual & $\begin{array}{l}\text { Self- } \\
\text { monitoring }\end{array}$ & NA & Online \\
\hline
\end{tabular}


Appendix A. Study characteristics and intervention components (continued)

\begin{tabular}{|c|c|c|c|c|c|c|c|c|c|c|c|c|}
\hline \multicolumn{2}{|l|}{ Background } & \multicolumn{2}{|c|}{ Participants } & \multicolumn{3}{|c|}{ Study characteristics } & \multicolumn{6}{|c|}{ Components of self-management interventions } \\
\hline Studies: & $\stackrel{\Xi}{\Xi}$ & 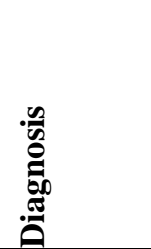 & $\mathbf{Z}$ & 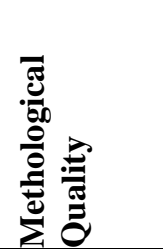 & 它 & 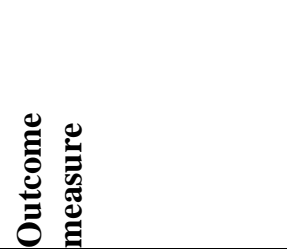 & 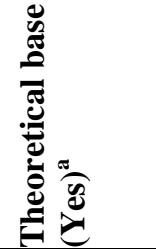 & 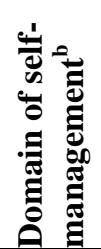 & 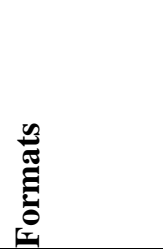 & 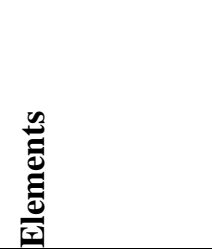 & 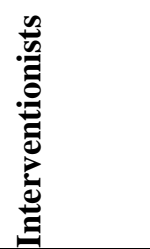 & 俤 \\
\hline $\begin{array}{l}\text { Laffel et al. } \\
2003 \text { [65] }\end{array}$ & USA & Diabetes & $\begin{array}{l}N=100 \\
I=50 \\
C=50\end{array}$ & Moderate & $\begin{array}{l}\text { Usual } \\
\text { care }\end{array}$ & $\begin{array}{l}\text { Quality of life } \\
\text { Symptoms }\end{array}$ & NA & $\mathrm{MM}$ & Individual & $\begin{array}{l}\text { Family } \\
\text { therapy } \\
\text { Education } \\
\text { Goal-setting } \\
\text { skills }\end{array}$ & $\begin{array}{l}\text { Research } \\
\text { assistant }\end{array}$ & Clinic \\
\hline $\begin{array}{l}\text { Mcpherson } \\
\text { et al. } 2006 \\
\text { [66] }\end{array}$ & $\begin{array}{l}\text { United } \\
\text { King- } \\
\text { dom }\end{array}$ & Asthma & $\begin{array}{l}N=101 \\
I=51 \\
C=50\end{array}$ & Moderate & $\begin{array}{l}\text { Another } \\
\text { specific } \\
\text { inter- } \\
\text { vention }\end{array}$ & $\begin{array}{l}\text { Disease knowledge } \\
\text { Symptoms }\end{array}$ & NA & MM & Individual & $\begin{array}{l}\text { Education } \\
\text { Self- } \\
\text { monitoring } \\
\text { Problem- } \\
\text { solving skills }\end{array}$ & NA & Home \\
\hline $\begin{array}{l}\text { Mulvaney et } \\
\text { al. } 2010 \\
{[67]}\end{array}$ & USA & $\begin{array}{l}\text { Diabetes } \\
\text { type } 1\end{array}$ & $\begin{array}{l}\mathrm{N}=49 \\
\mathrm{I}=31 \\
\mathrm{C}=18\end{array}$ & Moderate & $\begin{array}{l}\text { Usual } \\
\text { care }\end{array}$ & $\begin{array}{l}\text { Symptoms } \\
\text { Adherence }\end{array}$ & $\begin{array}{l}\text { CSL } \\
\text { Self- } \\
\text { determin } \\
\text { ation } \\
\text { theory }\end{array}$ & MM & Individual & $\begin{array}{l}\text { Problem- } \\
\text { solving skills } \\
\text { Peer-support }\end{array}$ & NA & Online \\
\hline $\begin{array}{l}\text { Naar-King } \\
\text { et al. } 2013 \\
{[68]}\end{array}$ & USA & HIV & $\begin{array}{l}T=76 \\
I=36 \\
C=40\end{array}$ & High & $\begin{array}{l}\text { Another } \\
\text { inter- } \\
\text { vention }\end{array}$ & $\begin{array}{l}\text { Adherence } \\
\text { Symptoms }\end{array}$ & $\begin{array}{l}\text { Principle } \\
\text { s of } \\
\text { motivatio } \\
\text { nal } \\
\text { interview }\end{array}$ & MM & Individual & $\begin{array}{l}\text { Education } \\
\text { Goal setting } \\
\text { skills }\end{array}$ & NA & Home \\
\hline
\end{tabular}




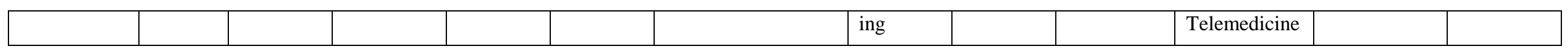

Appendix A. Study characteristics and intervention components (continued)

\begin{tabular}{|c|c|c|c|c|c|c|c|c|c|c|c|c|}
\hline \multicolumn{2}{|c|}{ Background } & \multicolumn{2}{|c|}{ Participants } & \multicolumn{3}{|c|}{ Study characteristics } & \multicolumn{6}{|c|}{ Components of self-management interventions } \\
\hline Studies: & $\stackrel{\vec{E}}{\Xi}$ & 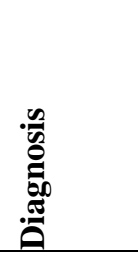 & $\mathbf{Z}$ & 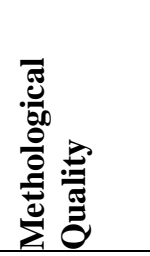 & 它 & 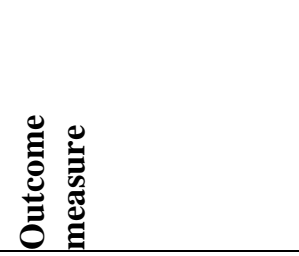 & 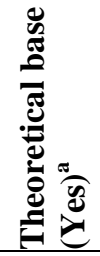 & 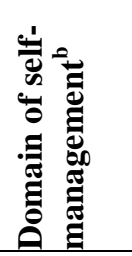 & 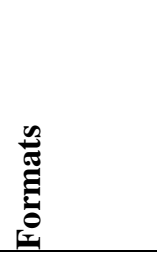 & 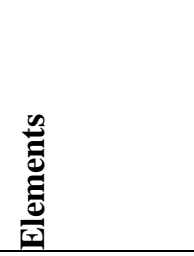 & 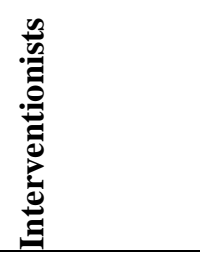 & 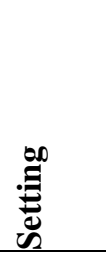 \\
\hline $\begin{array}{l}\text { Newcombe } \\
\text { et al. } 2012 \\
\text { [69] }\end{array}$ & $\begin{array}{l}\text { Au- } \\
\text { stralia }\end{array}$ & $\begin{array}{l}\text { Chronic } \\
\text { res- } \\
\text { piratory } \\
\text { con- } \\
\text { dition }\end{array}$ & $\begin{array}{l}\mathrm{N}=39 \\
\mathrm{I}=19 \\
\mathrm{C}=20\end{array}$ & High & Waitlist & $\begin{array}{l}\text { Psychological } \\
\text { outcomes } \\
\text { Dealing with the } \\
\text { chronic condition in } \\
\text { daily life }\end{array}$ & NA & MM & $\begin{array}{l}\text { Individual } \\
\text { Group } \\
\text { (online) }\end{array}$ & $\begin{array}{l}\text { Education } \\
\text { Self- } \\
\text { monitoring } \\
\text { Peer-support }\end{array}$ & NA & Online \\
\hline $\begin{array}{l}\text { Ng et al. } \\
2008 \text { [70] }\end{array}$ & China & Asthma & $\begin{array}{l}\mathrm{N}=37 \\
\mathrm{I}=20 \\
\mathrm{C}=17\end{array}$ & Moderate & Waitlist & $\begin{array}{l}\text { Quality of life } \\
\text { Symptoms }\end{array}$ & NA & $\begin{array}{l}\mathrm{MM}+\mathrm{R} \\
\mathrm{M}+\mathrm{EM}\end{array}$ & Group & $\begin{array}{l}\text { Education } \\
\text { Family } \\
\text { therapy }\end{array}$ & NA & Clinic \\
\hline $\begin{array}{l}\text { Nunn et al. } \\
2006 \text { [71] }\end{array}$ & $\begin{array}{l}\text { Au- } \\
\text { stralia }\end{array}$ & $\begin{array}{l}\text { Diabetes } \\
\text { type } 1\end{array}$ & $\begin{array}{l}N=139 \\
I=60 \\
C=63\end{array}$ & Moderate & $\begin{array}{l}\text { Usual } \\
\text { Care }\end{array}$ & Disease knowledge & NA & MM & Individual & $\begin{array}{l}\text { Education } \\
\text { Tele } \\
\text { medicine } \\
\text { Self- } \\
\text { monitoring }\end{array}$ & NA & Home \\
\hline $\begin{array}{l}\text { Palermo et } \\
\text { al. 2009 } \\
{[72]}\end{array}$ & USA & $\begin{array}{l}\text { Chronic } \\
\text { pain }\end{array}$ & $\begin{array}{l}\mathrm{N}=48 \\
\mathrm{I}=26 \\
\mathrm{C}=22\end{array}$ & High & Waitlist & $\begin{array}{l}\text { Symptoms } \\
\text { Psychological } \\
\text { outcomes }\end{array}$ & $\begin{array}{l}\text { CBT, } \\
\text { CSL }\end{array}$ & MM & Individual & $\begin{array}{l}\text { Education } \\
\text { Cognitive } \\
\text { restructuring }\end{array}$ & Psychologist & Online \\
\hline
\end{tabular}




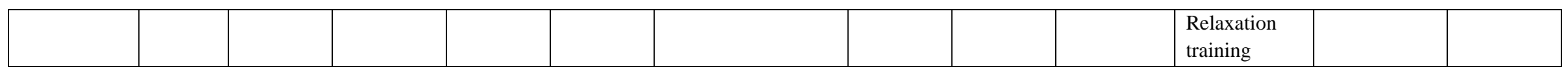

Appendix A. Study characteristics and intervention components (continued)

\begin{tabular}{|c|c|c|c|c|c|c|c|c|c|c|c|c|}
\hline \multicolumn{2}{|l|}{ Background } & \multicolumn{2}{|c|}{ Participants } & \multicolumn{3}{|c|}{ Study characteristics } & \multicolumn{6}{|c|}{ Components of self-management interventions } \\
\hline Studies: & 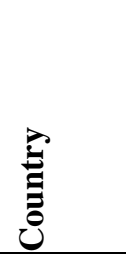 & 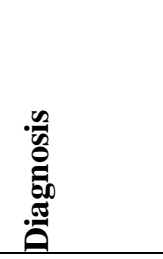 & $\mathbf{Z}$ & 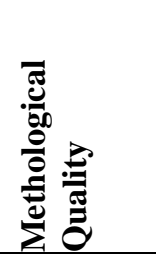 & $\bar{\Xi}$ & 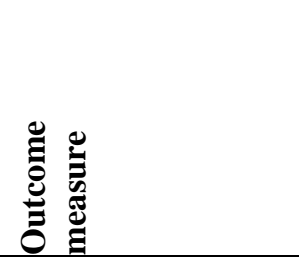 & 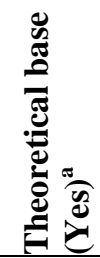 & 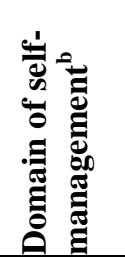 & 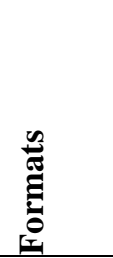 & 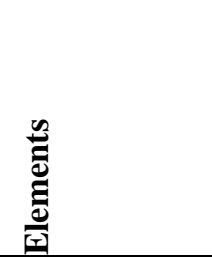 & 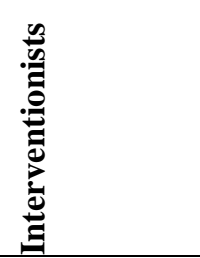 & $\stackrel{\infty}{\stackrel{\infty}{E}}$ \\
\hline $\begin{array}{l}\text { Pulgaron et } \\
\text { al. } 2010 \\
{[73]}\end{array}$ & USA & Asthma & $\begin{aligned} \mathrm{N} & =41 \\
\mathrm{I} & =20 \\
\mathrm{C} & =21\end{aligned}$ & Moderate & $\begin{array}{l}\text { Usual } \\
\text { care }\end{array}$ & $\begin{array}{l}\text { Disease knowledge } \\
\text { Dealing with the } \\
\text { chronic condition in } \\
\text { daily life }\end{array}$ & NA & MM & Group & $\begin{array}{l}\text { Education } \\
\text { Problem } \\
\text { solving skills } \\
\text { Peer-support }\end{array}$ & $\begin{array}{l}\text { Psychologist } \\
\text { (under- } \\
\text { graduate } \\
\text { degree) }\end{array}$ & Camp \\
\hline $\begin{array}{l}\text { Rhee et al. } \\
2011 \text { [74] }\end{array}$ & USA & Asthma & $\begin{array}{l}N=91 \\
I=46 \\
C=45\end{array}$ & Moderate & $\begin{array}{l}\text { Another } \\
\text { specific } \\
\text { inter- } \\
\text { vention }\end{array}$ & $\begin{array}{l}\text { Quality of life } \\
\text { Symptoms }\end{array}$ & NA & $\begin{array}{l}\mathrm{MM}+\mathrm{R} \\
\mathrm{M}\end{array}$ & Group & $\begin{array}{l}\text { Discussion } \\
\text { Education } \\
\text { Tele- } \\
\text { medicine } \\
\text { Peer support }\end{array}$ & NA & Camp \\
\hline $\begin{array}{l}\text { Scholten et } \\
\text { al. } 2013 \\
{[75]}\end{array}$ & $\begin{array}{l}\text { Nether- } \\
\text { lands }\end{array}$ & $\begin{array}{l}\text { Chronic } \\
\text { condition }\end{array}$ & $\begin{array}{l}\mathrm{N}=194 \\
\mathrm{I} 1=71 \\
\mathrm{I} 2=49 \\
\mathrm{C}=74\end{array}$ & Moderate & Waitlist & $\begin{array}{l}\text { Psychological } \\
\text { outcomes }\end{array}$ & NA & $\begin{array}{l}\mathrm{MM}+ \\
\mathrm{EM}+ \\
\mathrm{RM}\end{array}$ & Group & $\begin{array}{l}\text { Education } \\
\text { Relaxation } \\
\text { techniques } \\
\text { Cognitive } \\
\text { restructuring } \\
\text { Social skills }\end{array}$ & Psychologist & $\begin{array}{l}\text { Clinic } \\
\text { School }\end{array}$ \\
\hline
\end{tabular}




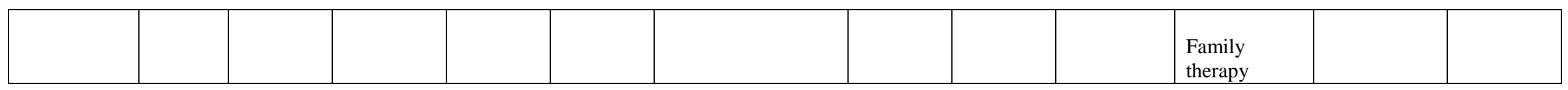

Appendix A. Study characteristics and intervention components (continued)

\begin{tabular}{|c|c|c|c|c|c|c|c|c|c|c|c|c|}
\hline \multicolumn{2}{|l|}{ Background } & \multicolumn{2}{|c|}{ Participants } & \multicolumn{3}{|c|}{ Study characteristics } & \multicolumn{6}{|c|}{ Components of self-management interventions } \\
\hline Studies: & $\stackrel{\Xi}{\Xi}$ & 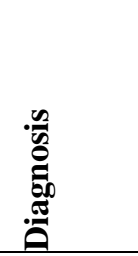 & $\mathbf{Z}$ & 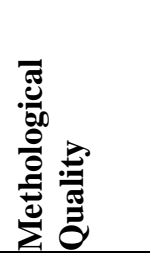 & $\bar{\Xi}$ & 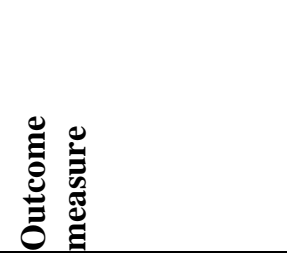 & 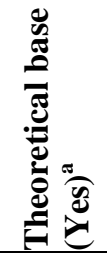 & 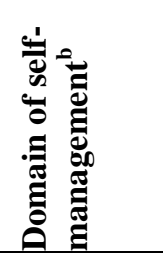 & 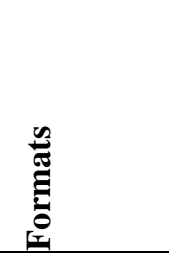 & 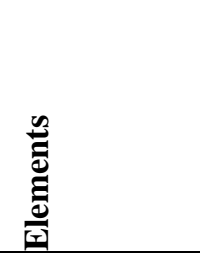 & .气̊̃ & 包 \\
\hline $\begin{array}{l}\text { Shames et } \\
\text { al. } 2004 \\
{[76]}\end{array}$ & USA & Asthma & $\begin{array}{l}N=119 \\
I=59 \\
C=60\end{array}$ & Moderate & $\begin{array}{l}\text { Usual } \\
\text { care }\end{array}$ & $\begin{array}{l}\text { Symptoms } \\
\text { Disease knowledge }\end{array}$ & NA & $\mathrm{MM}$ & Individual & $\begin{array}{l}\text { Education } \\
\text { Tele- } \\
\text { medicine }\end{array}$ & $\begin{array}{l}\text { Case } \\
\text { manager } \\
\text { Clinician } \\
\text { Nurse }\end{array}$ & $\begin{array}{l}\text { Clinic } \\
\text { Home }\end{array}$ \\
\hline $\begin{array}{l}\text { Staab et al. } \\
2006 \text { [77] }\end{array}$ & $\begin{array}{l}\text { Ger- } \\
\text { many }\end{array}$ & $\begin{array}{l}\text { Atopic } \\
\text { derma- } \\
\text { titis }\end{array}$ & $\begin{array}{l}N=823 \\
I=446 \\
C=377\end{array}$ & Moderate & $\begin{array}{l}\text { Another } \\
\text { specific } \\
\text { inter- } \\
\text { vention }\end{array}$ & Symptoms & NA & $\mathrm{MM}+\mathrm{EM}$ & Group & $\begin{array}{l}\text { Education } \\
\text { Peer-support } \\
\text { Relaxation } \\
\text { training }\end{array}$ & $\begin{array}{l}\begin{array}{l}\text { Derma- } \\
\text { tologist }\end{array} \\
\text { Pediatrician } \\
\text { Psychologist } \\
\text { Dieticians }\end{array}$ & Clinic \\
\hline
\end{tabular}


Appendix A. Study characteristics and intervention components (continued)

\begin{tabular}{|c|c|c|c|c|c|c|c|c|c|c|c|c|}
\hline \multicolumn{2}{|l|}{ Background } & \multicolumn{2}{|c|}{ Participants } & \multicolumn{3}{|c|}{ Study characteristics } & \multicolumn{6}{|c|}{ Components of self-management interventions } \\
\hline Studies: & 离 & 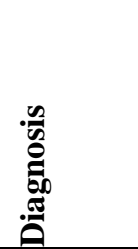 & Z & 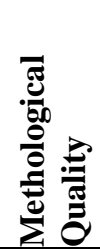 & 总 & 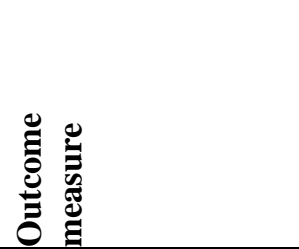 & 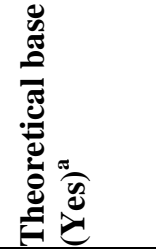 & 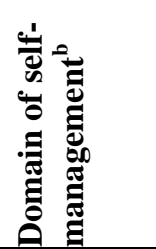 & 号 & 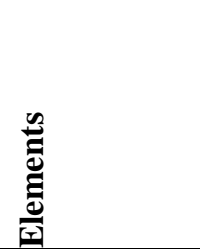 & 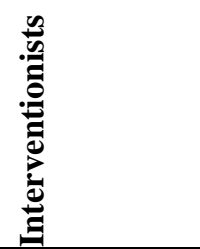 & : \\
\hline $\begin{array}{l}\text { Stinson et } \\
\text { al. } 2010 \\
{[78]}\end{array}$ & Canada & $\begin{array}{l}\text { Juvenile } \\
\text { Idio- } \\
\text { pathic } \\
\text { Arthritis }\end{array}$ & $\begin{array}{l}\mathrm{N}=46 \\
\mathrm{I}=22 \\
\mathrm{C}=24\end{array}$ & High & $\begin{array}{l}\text { Another } \\
\text { specific } \\
\text { inter- } \\
\text { vention }\end{array}$ & $\begin{array}{l}\text { Quality of life } \\
\text { Symptoms } \\
\text { Psychological } \\
\text { outcomes } \\
\text { Adherence } \\
\text { Disease knowledge } \\
\text { Dealing with the } \\
\text { chronic condition in } \\
\text { daily life }\end{array}$ & NA & $\begin{array}{l}\mathrm{MM}+\mathrm{R} \\
\mathrm{M}+\mathrm{EM}\end{array}$ & Individual & $\begin{array}{l}\text { Education } \\
\text { Tele- } \\
\text { medicine }\end{array}$ & $\begin{array}{l}\text { Psychologist } \\
\text { (under- } \\
\text { graduate } \\
\text { degree) }\end{array}$ & Online \\
\hline $\begin{array}{l}\text { Stulemeijer } \\
\text { et al. } 2005 \\
\text { [79] }\end{array}$ & $\begin{array}{l}\text { Nether- } \\
\text { lands }\end{array}$ & $\begin{array}{l}\text { Chronic } \\
\text { Fatigue } \\
\text { Syn- } \\
\text { drome }\end{array}$ & $\begin{array}{l}\mathrm{N}=71 \\
\mathrm{I}=36 \\
\mathrm{C}=35\end{array}$ & High & $\begin{array}{l}\text { Waiting } \\
\text { list }\end{array}$ & $\begin{array}{l}\text { Symptoms } \\
\text { School attendance }\end{array}$ & CBT & $\begin{array}{l}\mathrm{MM}+ \\
\mathrm{RM}+\mathrm{EM}\end{array}$ & Individual & $\begin{array}{l}\text { Education } \\
\text { Cognitive } \\
\text { restructuring }\end{array}$ & Psychologist & Clinic \\
\hline $\begin{array}{l}\text { Velsor- } \\
\text { Friedrich et } \\
\text { al. } 2005 \\
{[80]}\end{array}$ & USA & Asthma & $\begin{array}{l}\mathrm{N}=52 \\
\mathrm{I}=28 \\
\mathrm{C}=24\end{array}$ & Low & $\begin{array}{l}\text { Usual } \\
\text { care }\end{array}$ & Symptoms & $\begin{array}{l}\text { Orem's } \\
\text { Self-Care } \\
\text { Deficit } \\
\text { Theory } \\
\text { of }\end{array}$ & $\begin{array}{l}\text { MM+ } \\
\text { RM }\end{array}$ & $\begin{array}{l}\text { Invididual } \\
\text { Group }\end{array}$ & $\begin{array}{l}\text { Education } \\
\text { Peer-support }\end{array}$ & $\begin{array}{l}\text { Nurse } \\
\text { practitioner }\end{array}$ & School \\
\hline
\end{tabular}




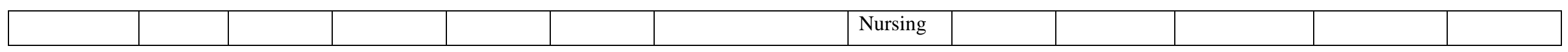

Appendix A. Study characteristics and intervention components (continued)

\begin{tabular}{|c|c|c|c|c|c|c|c|c|c|c|c|c|}
\hline \multicolumn{2}{|c|}{ Background } & \multicolumn{2}{|c|}{ Participants } & \multicolumn{3}{|c|}{ Study characteristics } & \multicolumn{6}{|c|}{ Components of self-management interventions } \\
\hline Studies: & 总 & 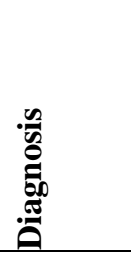 & Z & 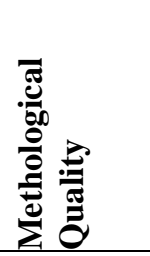 & 它 & 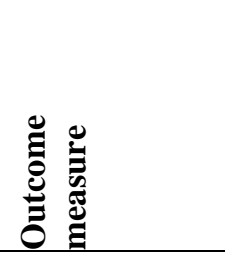 & 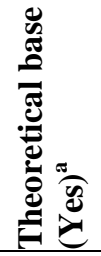 & 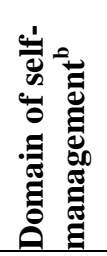 & 苞 & 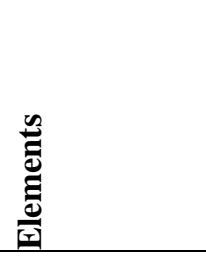 & 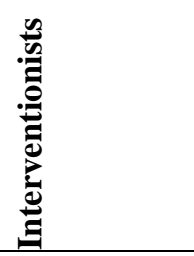 & : \\
\hline $\begin{array}{l}\text { Walders et } \\
\text { al. } 2006 \\
{[81]}\end{array}$ & USA & Asthma & $\begin{array}{l}N=175 \\
I=89 \\
C=86\end{array}$ & Moderate & $\begin{array}{l}\text { Usual } \\
\text { care }\end{array}$ & $\begin{array}{l}\text { Symptoms } \\
\text { Quality of life }\end{array}$ & NA & $\mathrm{MM}$ & Individual & $\begin{array}{l}\text { Education } \\
\text { Problem- } \\
\text { solving skills } \\
\text { Telemedicine }\end{array}$ & $\begin{array}{l}\text { Nurse } \\
\text { Asthma } \\
\text { social } \\
\text { worker } \\
\text { Psychologist }\end{array}$ & Clinic \\
\hline $\begin{array}{l}\text { Wiecha et } \\
\text { al. } 2005 \\
{[82]}\end{array}$ & USA & Asthma & $\begin{array}{l}\mathrm{N}=58 \\
\mathrm{I}=37 \\
\mathrm{C}=20\end{array}$ & Low & $\begin{array}{l}\text { Usual } \\
\text { Care }\end{array}$ & $\begin{array}{l}\text { Symptoms } \\
\text { Adherence }\end{array}$ & SCL & MM & Individual & $\begin{array}{l}\text { Education } \\
\text { Self- } \\
\text { monitoring } \\
\text { Peer-support } \\
\text { Discussion }\end{array}$ & $\begin{array}{l}\text { Physician } \\
\text { Research } \\
\text { assistant }\end{array}$ & Home \\
\hline
\end{tabular}


Appendix A. Study characteristics and intervention components (continued)

\begin{tabular}{|c|c|c|c|c|c|c|c|c|c|c|c|c|}
\hline \multicolumn{2}{|c|}{ Background } & \multicolumn{2}{|c|}{ Participants } & \multicolumn{3}{|c|}{ Study characteristics } & \multicolumn{6}{|c|}{ Components of self-management interventions } \\
\hline Studies: & 总 & 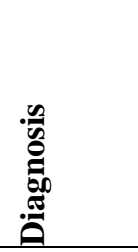 & $\mathbf{Z}$ & 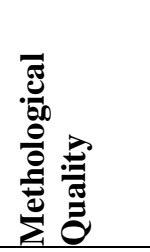 & 它 & 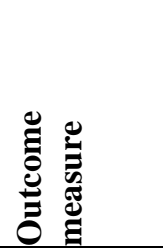 & 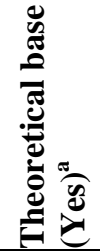 & 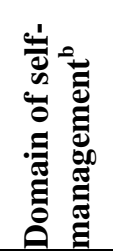 & 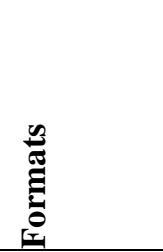 & 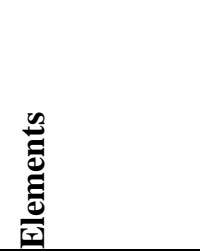 & 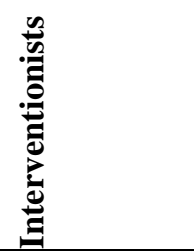 & 象 \\
\hline $\begin{array}{l}\text { Wysocki et } \\
\text { al. } 2007 \\
\text { [83] }\end{array}$ & USA & Diabetes & $\begin{array}{c}\mathrm{N}=104 \\
\mathrm{I}=28 \\
\mathrm{C} 1=31 \\
\mathrm{C} 2=26\end{array}$ & Moderate & $\begin{array}{l}\text { Another } \\
\text { specific } \\
\text { inter- } \\
\text { vention } \\
\text { Usual } \\
\text { care }\end{array}$ & $\begin{array}{l}\text { Symptoms } \\
\text { Adherence }\end{array}$ & NA & $\begin{array}{l}\text { MM+ } \\
\text { RM }\end{array}$ & Individual & $\begin{array}{l}\text { Problem } \\
\text { solving skills } \\
\text { Family } \\
\text { therapy } \\
\text { Communi- } \\
\text { cation skills } \\
\text { Education } \\
\text { Cognitive } \\
\text { restructuring }\end{array}$ & Psychologist & Clinic \\
\hline
\end{tabular}

${ }^{\text {a }} \mathrm{NA}=$ Not available CSL $=$ Cognitive social learning theory; $\mathrm{CBT}=$ cognitive behavioral theory

${ }^{\mathrm{b}} \mathrm{MM}=$ Medical Management; $\mathrm{EM}=$ Emotion Management; $\mathrm{RM}=$ Role Management (according Lorig \& Holman, 2003) 